\title{
Observations and a Model of the Mean Circulation over the Middle Atlantic Bight Continental Shelf
}

\author{
STEVEN J. LENTZ \\ Woods Hole Oceanographic Institution, Woods Hole, Massachusetts
}

(Manuscript received 24 January 2007, in final form 29 October 2007)

\begin{abstract}
Analyses of current time series longer than 200 days from 33 sites over the Middle Atlantic Bight continental shelf reveal a consistent mean circulation pattern. The mean depth-averaged flow is equatorward, alongshelf, and increases with increasing water depth from $3 \mathrm{~cm} \mathrm{~s}^{-1}$ at the $15-\mathrm{m}$ isobath to $10 \mathrm{~cm} \mathrm{~s}^{-1}$ at the $100-\mathrm{m}$ isobath. The mean cross-shelf circulation exhibits a consistent cross-shelf and vertical structure. The near-surface flow is typically offshore (positive, range -3 to $6 \mathrm{~cm} \mathrm{~s}^{-1}$ ). The interior flow is onshore and remarkably constant $\left(-0.2\right.$ to $\left.-1.4 \mathrm{~cm} \mathrm{~s}^{-1}\right)$. The near-bottom flow increases linearly with increasing water depth from $-1 \mathrm{~cm} \mathrm{~s}^{-1}$ (onshore) in shallow water to $4 \mathrm{~cm} \mathrm{~s}^{-1}$ (offshore) at the 250-m isobath over the slope, with the direction reversal near the 50-m isobath.

A steady, two-dimensional model (no along-isobath variations in the flow) reproduces the main features of the observed circulation pattern. The depth-averaged alongshelf flow is primarily driven by an alongshelf pressure gradient (sea surface slope of $3.7 \times 10^{-8}$ increasing to the north) and an opposing mean wind stress that also drives the near-surface offshore flow. The alongshelf pressure gradient accounts for both the increase in the alongshelf flow with water depth and the geostrophic balance onshore flow in the interior. The increase in the near-bottom offshore flow with water depth is due to the change in the relative magnitude of the contributions from the geostrophic onshore flow that dominates in shallow water and the offshore flow driven by the bottom stress that dominates in deeper water.
\end{abstract}

\section{Introduction}

It has been $25 \mathrm{yr}$ or more since the overviews of the mean circulation of the Middle Atlantic Bight (MAB) and Georges Bank continental shelves by Bumpus (1973), Beardsley et al. (1976), and Beardsley and Boicourt (1981). In that time the number of currentmeter records of more than 6-month duration in the MAB has increased substantially as a result of several major field programs including the Nantucket Shoals Flux Experiment (NSFE) (Beardsley et al. 1985), the Shelf Edge Exchange Processes (SEEP-I and SEEP-II) studies (Walsh et al. 1988; Aikman et al. 1988; Biscaye et al. 1994; Shaw et al. 1994), the Coastal Mixing and Optics (CMO) study (Shearman and Lentz 2003), the Minerals Management Service Hatteras Study off North Carolina (Churchill and Berger 1998), and the Global Ocean Ecosystems Dynamics (GLOBEC)

Corresponding author address: Steven J. Lentz, Woods Hole Oceanographic Institution, MS 21, Woods Hole, MA 02543.

E-mail: slentz@whoi.edu
Georges Bank study (Werner et al. 2003; Irish et al. 2005). Additional long-term current observations over the inner shelf have been made at the Martha's Vineyard Coastal Observatory (MVCO) (Austin et al. 2002) and the Long-term Ecosystem Observatory (LEO-15) off New Jersey (Schofield et al. 2002). With the recent interest in climate and coastal observatories, it seems timely to review what is known about the MAB mean circulation and dynamics in the context of these more recent moored observations. A quote from Bumpus (1973) seems appropriate to the present situation:

Inasmuch as the literature about the [east coast of the United States] continental shelf is copious and scattered, it appears warranted to this author to review the information we now have to provide a firm basis for designing future research programs.

Current time series of 200 days or longer over the MAB shelf were collected and analyzed to characterize the mean circulation pattern. The main features of the observed circulation pattern are shown to be quantitatively consistent with a simple dynamical model, similar to a model originally proposed by Csanady (1976). 


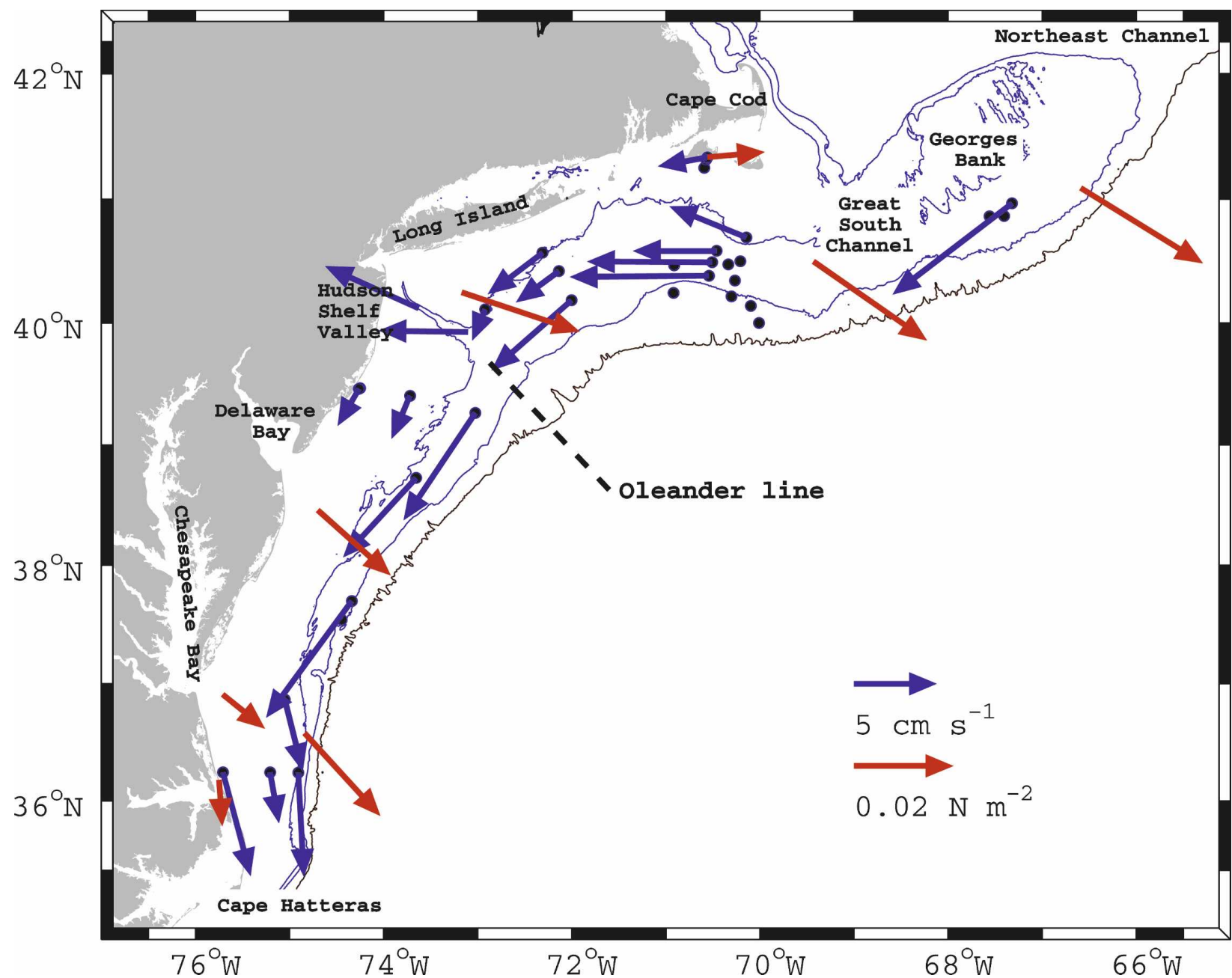

FIG. 1. Map of the Middle Atlantic Bight showing locations of current time series longer than 200 days, mean depth-averaged current vectors (blue), and mean wind stress vectors (red). For clarity, only selected mean current vectors are shown for sites south of Cape Cod and on the southern flank of Georges Bank. The 50-, 100-, and 1000-m isobaths, and the approximate location of the Oleander line (Flagg et al. 2006) are also shown.

\section{Background}

A thorough and very interesting overview of what was known about the MAB mean circulation and dynamics prior to 1981 is presented by Beardsley and Boicourt (1981). A briefer, updated overview is given here for completeness.

The MAB continental shelf extends from Cape Hatteras (North Carolina) in the south to Nantucket Shoals (south of Cape Cod, Massachusetts) in the northeast (Fig. 1). The southern flank of Georges Bank is included as part of the MAB in this study because it is continuous with the MAB shelf to the west for water depths greater than $60 \mathrm{~m}$. The southern flank of Georges Bank is separated from the Scotian shelf to the northeast by the 200-m-deep Northeast Channel and from the MAB to the southwest by the 60-m-deep Great South Channel. The Hudson shelf valley extends across almost the entire MAB shelf separating the New England shelf (between Great South Channel and Hudson shelf valley) from the central MAB (between Hudson shelf valley and Chesapeake Bay). The coastline and isobath orientations are aligned roughly northeastsouthwest on the southern flank of Georges Bank and in the central MAB, east-west on the New England shelf, and north-south in the southern MAB (between Chesapeake Bay and Cape Hatteras). The MAB shelf width decreases from about $100 \mathrm{~km}$ in the northern half of the MAB to less than $30 \mathrm{~km}$ at Cape Hatteras. The depth of the shelf break also decreases from $\sim 100 \mathrm{~m}$ in the north to $40 \mathrm{~m}$ or less in the southern MAB. The bottom slope $\left(h_{x}\right)$ over the shelf varies, but is typically 
$6 \times 10^{-4}$, except onshore of the 20 -m isobath where the bottom is steeper by a factor of $5-10$.

Mean wind stresses are $\sim 0.03 \mathrm{~N} \mathrm{~m}^{-2}$ toward the southeast and spatially uniform (Fig. 1). The mean wind stress is weak compared to the variability on time scales of days (standard deviations of $\approx 0.1 \mathrm{~N} \mathrm{~m}^{-2}$ ) (e.g., Saunders 1977). There is also a spatially uniform seasonal variation with monthly mean wind stresses of 0.07 $\mathrm{N} \mathrm{m}^{-2}$ southeastward in winter (December and January) and $0.02 \mathrm{~N} \mathrm{~m}^{-2}$ northeastward in summer (June to August) (Lentz 2008).

The shelf waters of the MAB and Georges Bank exhibit a large seasonal variation in both temperature and stratification (e.g., Bigelow 1933; Mayer et al. 1979; Beardsley et al. 1985; Lentz et al. 2003; Lentz 2008). In summer, the water is warm and thermally stratified due to strong surface heating and weak wind stresses. In winter, the water is cold and weakly stratified due to surface cooling and stronger wind stresses. Salinity over the shelf increases from about 32 near the coast to about 34 at the shelf break due to river discharges both within the MAB and to the north (Bigelow and Sears 1935; Chapman and Beardsley 1989; Loder et al. 1998; Lentz 2008). A front, located near the shelf break, separates the cooler, fresher shelf water from the warmer, saltier slope water (e.g., Bigelow and Sears 1935; Linder and Gawarkiewicz 1998; Fratantoni and Pickart 2007).

Relative to other shelves, the MAB shelf is moderately wide, with a small bottom slope, a large seasonal variation in stratification, and it is strongly influenced by freshwater runoff and the presence of a shelf-slope front. The slope Burger number, defined as $h_{x} N / f$, is less than 0.1 for the MAB shelf, where $N \sim 0^{-2} \mathrm{~s}^{-1}$ is the buoyancy frequency and $f \sim 10^{-4} \mathrm{~s}^{-1}$ is the Coriolis frequency. This is small relative to, for example, continental shelves on the west coast of the United States and suggests the shelf response should be relatively barotropic.

A sequence of studies using salinity and oxygen isotopic ratios $\left(\delta^{18} \mathrm{O}\right)$ as tracers have shown that the MAB shelf circulation is part of a continuous coastal current extending from Greenland to Cape Hatteras (Chapman et al. 1986; Chapman and Beardsley 1989; Loder et al. 1998; Khatiwala et al. 1999). The mean flow over the MAB shelf is southwestward along-isobath at 5-10 $\mathrm{cm} \mathrm{s}^{-1}$ based on hydrography, drifters, shipboard current profiles, and moored current observations (e.g., Bigelow 1915; Bumpus 1973; Beardsley et al. 1976; Linder and Gawarkiewicz 1998; Lozier and Gawarkiewicz 2001; Shearman and Lentz 2003; Brink et al. 2003; Flagg and Dunn 2003; Flagg et al. 2006). This mean flow turns offshore near Cape Hatteras and is entrained into the Gulf Stream (Bumpus 1973; Ford et al. 1952; Churchill and Berger 1998; Savidge and Bane 2001; Pietrafesa et al. 2002; Gawarkiewicz and Linder 2006). The alongshelf mean flow increases with height above the bottom and distance offshore (Beardsley et al. 1976).

The structure and magnitude of the mean cross-shelf circulation is less clear. Beardsley et al. (1976) note a tendency in moored current observations for onshore veering of the flow with depth. Bumpus (1965) inferred a divergence in the near-bottom cross-shelf flow with onshore flow shoreward of the $60-\mathrm{m}$ isobath and offshore flow seaward of the $60-\mathrm{m}$ isobath based on the small number of seabed drifters recovered that were deployed seaward of the $60-\mathrm{m}$ isobath.

The dynamics of the mean circulation over the MAB shelf remain uncertain, in part because there have been few quantitative tests of dynamical models of the mean circulation. It has long been assumed that the MAB mean circulation is not driven solely by the local wind stress, which would tend to force an eastward flow on the New England shelf, opposite the observed mean circulation (Fig. 1). Iselin (1939) argued that the MAB mean circulation is maintained by the cross-shelf buoyancy forcing associated with less dense (fresher) water near the coast. Subsequently, Sverdrup et al. (1942) argued that the southwestward flow was due to a poleward alongshelf pressure gradient estimated from geodetic leveling of tide gauges. However, subsequent studies suggested geodetic leveling was not accurate enough to determine the alongshelf pressure gradient (Sturges 1977). Stommel and Leetmaa (1972) found that a steady, two-dimensional model (no alongshelf variations) forced by the mean wind stress and freshwater runoff could not account for the observed mean flow in the MAB and concluded there must be an alongshore sea surface slope $\eta_{y}$ of order $10^{-7}$ to drive the observed mean alongshelf flow equatorward. Scott and Csanady (1976) subsequently estimated $\eta_{y}$ to be $1.4 \times 10^{-7}$ over the inner shelf off Long Island, New York, from the intercept of a linear regression analysis of the form $\tau^{s y} / \rho_{o}=r v_{b}+g h \eta_{y}$, where $\tau^{s y}$ is the alongshelf wind stress, $\rho_{o}$ is the seawater density, $r$ is a linear drag, $v_{b}$ is the near-bottom alongshelf velocity, $g$ is gravitational acceleration, and $h$ is the water depth. The source of the inferred alongshelf pressure gradient has not been determined. Along-isobath buoyancy gradients associated with freshwater runoff extending as far north as the Arctic, the large-scale offshore circulation, or an upstream source have been suggested as possible causes (e.g., Beardsley and Winant 1979; Chapman et al. 1986). On the basis of model results, Beardsley and Winant (1979) argue that the alongshelf pressure gradient is imposed by the larger-scale circulation (Csan- 
ady 1978). However, subsequent studies using simple barotropic models with bottom friction suggested that an alongshelf pressure gradient associated with the large-scale general circulation could not drive the shelfmean flow because the pressure gradient did not penetrate onto the shelf (Wang 1982; Chapman et al. 1986). The source of the inferred alongshelf pressure gradient is discussed further in section $6 \mathrm{a}$.

In a particularly insightful study, Csanady (1976) used a steady, two-dimensional, constant eddy-viscosity model over a sloping bottom, similar to the model of Stommel and Leetmaa (1972), to examine the dynamics of the MAB mean circulation. The model was forced by alongshelf and cross-shelf wind stress, a cross-shelf density gradient (buoyancy force), and an alongshelf pressure gradient. Csanady pointed out that for a spatially uniform alongshelf pressure gradient, the equatorward alongshelf mean flow should increase with water depth as observed. He also noted that the alongshelf pressure gradient accounts for the change in sign of the nearbottom cross-shelf flow suggested by the bottom drifter observations (Bumpus 1965). Modified versions of Csanady's model with imposed alongshelf pressure gradients reproduce the main qualitative features of the mean circulation over both the southwest Nova Scotia shelf (Smith 1983) and the southern flank of Georges Bank (Butman et al. 1987).

\section{Mean circulation model}

Characteristics of the observed mean circulation (described in sections $5 \mathrm{a}$ and $5 \mathrm{~b}$ ) are compared to a modified version of Csanady's model developed in this section. The model developed here avoids choosing an eddy viscosity by assuming constant surface and bottom boundary layer thicknesses and decomposing the flow into geostrophic and stress-driven boundary layer (Ekman) components (Fig. 2; Dever 1997). A right-handed coordinate system is used with $y$ aligned alongshelf positive poleward, $x$ positive offshore, and $z$ positive upward.

\section{a. Model equations}

The mean alongshelf and cross-shelf currents vary in the cross-shelf direction, but do not exhibit any systematic variation along isobaths, except in the vicinity of Cape Hatteras (see sections 5a and 5b). This result indicates that a reasonable first approximation is to assume there are no alongshelf variations in the mean flow. With this assumption, assuming $\eta \ll h$, and the boundary condition of no cross-shelf transport $U$ at the coast, volume conservation implies

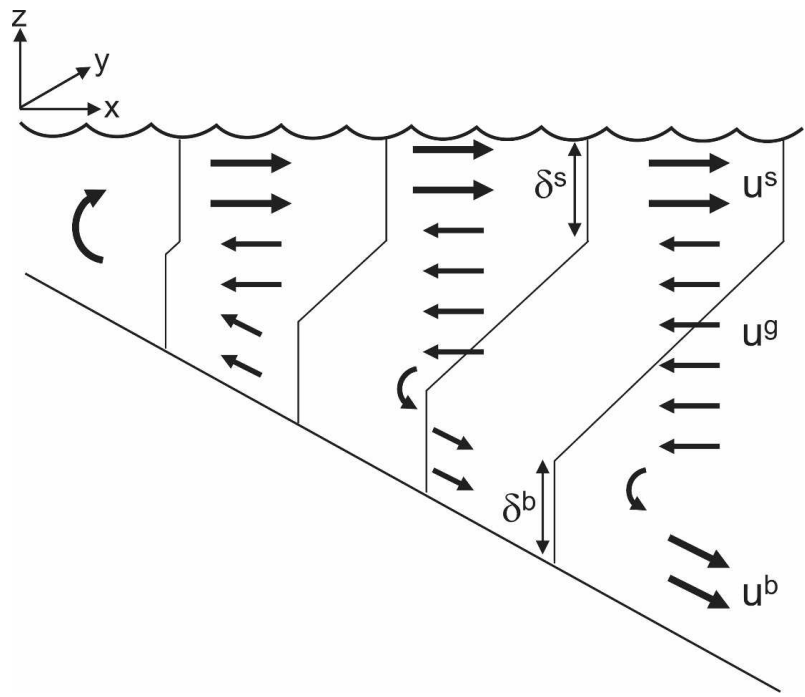

FIG. 2. Schematic of the two-dimensional model setup. The model assumes a geostrophic interior and vertically mixed surface and bottom boundary layers of constant thickness $\delta^{s}$ and $\delta^{b}$, respectively. The thin lines are isopycnals and the bottom slope is $h_{x}$. The inferred mean cross-shelf circulation is also shown with offshore flow $u^{s}$ in the surface boundary layer, onshore flow $u^{g}$ in the interior, and divergent flow $u^{b}$ in the bottom boundary layer with onshore flow near the coast increasing to offshore flow as the water depth increases. Vertical velocities suggested by convergences and divergences in cross-shelf flow are also shown.

$$
U=\int_{-h}^{0} u(z) d z=u^{\mathrm{da}} h=0
$$

everywhere, where $u$ is the mean cross-shelf velocity and superscript "da" indicates the depth-average flow.

The momentum balances are assumed to be steady and linear; that is, the nonlinear advective terms are assumed to be small. The alongshelf momentum balance,

$$
\rho_{o} f u=-P_{y}+\tau_{z}^{y}
$$

consists of three terms: the Coriolis force $f u$, the alongshelf pressure gradient $P_{y}$, and the alongshelf stress divergence $\tau_{z}^{y}$. Subscripts $(x, y, z)$ indicate partial derivatives. The cross-shelf momentum balance is assumed to be geostrophic,

$$
-\rho_{o} f v=-P_{x},
$$

where $v$ is the alongshelf velocity. Previous observational studies indicate that the alongshelf velocity is primarily geostrophic at subtidal time scales (Brown et al. 1985; Lentz et al. 1999; Shearman and Lentz 2003), assuming, however, a geostrophic balance neglects cross-shelf wind stress and wave forcing that may be important in shallow water (Lentz et al. 1999; Fewings et al. 2008; Lentz et al. 2008). A derivation including $\tau_{z}^{x}$ 
in (3) is given in appendix A. The contributions of $\tau_{z}^{x}$ to the MAB mean circulation are small except over the inner shelf where $h \approx \delta^{b}$ (the bottom boundary layer thickness).

\section{b. Estimating the cross-shelf circulation}

The cross-shelf circulation is assumed to consist of cross-shelf Ekman transports in the surface and bottom boundary layers and a geostrophic cross-shelf flow extending from the surface to the bottom. Surface and bottom Ekman velocities, vertically averaged over the boundary layers, are

$$
u^{s e}=\frac{\tau^{s y}}{\rho_{o} f \delta^{s}} \quad \text { and } \quad u^{b e}=-\frac{\tau^{b y}}{\rho_{o} f \delta^{b}},
$$

where $\tau^{b y}$ is the alongshelf component of the bottom stress, and $\delta^{s}$ and $\delta^{b}$ are surface and bottom boundary layer thicknesses. Assuming the flow is hydrostatic, $P_{z}=-g \rho$, the geostrophic cross-shelf velocity is

$$
u^{g}=-\frac{P_{y}}{\rho_{o} f}=-\frac{g \eta_{y}}{f}-\frac{B_{y}}{f}, \text { where } B_{y}=g \int_{z}^{0} \frac{\rho_{y}}{\rho_{o}} d z^{\prime}
$$

is the alongshelf buoyancy gradient and $\rho$ is density. From the alongshelf momentum balance (2), the steady cross-shelf current is geostrophic in the interior where $\tau_{z}^{y} \approx 0$.

Integrating (2) from the surface to the bottom and using (1) and (5) yields

$$
\int_{-h}^{0} \frac{P_{y}}{\rho_{o}} d z=g h \eta_{y}+\int_{-h}^{0} B_{y} d z=\frac{\tau^{s y}-\tau^{b y}}{\rho_{o}} .
$$

Note that dividing (6) by $f$ and using (4) indicates that the sum of the geostrophic and Ekman cross-shelf transports is zero,

$$
\int_{-h}^{0} u^{g} d z+u^{s e} \delta^{s}+u^{b e} \delta^{b}=0,
$$

as it must be from (1).

Offshore of the inner shelf, where the surface and bottom boundary layers do not overlap $\left(h>\delta^{s}+\delta^{b}\right)$, the vertical average of the cross-shelf velocity in the surface boundary layer is the sum of the Ekman (4) and geostrophic velocities (5),

$u^{s}=u^{s e}+\frac{1}{\delta^{s}} \int_{\delta^{s}}^{0} u^{g} d z=\frac{\tau^{s y}}{\rho_{o} f \delta^{s}}-\frac{g \eta_{y}}{f}-\frac{1}{f \delta^{s}} \int_{\delta^{s}}^{0} B_{y} d z$.
Similarly, the vertical average of the cross-shelf velocity in the bottom boundary layer is

$$
\begin{aligned}
u^{b} & =u^{b e}+\frac{1}{\delta^{b}} \int_{-h}^{-h+\delta^{b}} u^{g} d z \\
& =-\frac{\tau^{s y}}{\rho_{o} f \delta^{b}}+\frac{g h \eta_{y}}{f \delta^{b}}\left(1-\frac{\delta^{b}}{h}\right)+\frac{1}{f \delta^{b}} \int_{-h+\delta^{b}}^{0} B_{y} d z,
\end{aligned}
$$

where (6) was used to express $\tau^{b y}$ in terms of $\tau^{s y}, \eta_{y}$, and $B_{y}$.

\section{c. Estimating the alongshelf velocity}

To estimate the geostrophic alongshelf velocity, assume the flow is hydrostatic, which implies a thermal wind balance:

$$
v_{z}^{g}=-\frac{g \rho_{x}}{f \rho_{o}}
$$

Several previous observational studies support a thermal wind balance, even over the inner shelf (Lentz et al. 1999; Shearman and Lentz 2003; Garvine 2004; Codiga 2005). Integrating the thermal wind balance (9) from the bottom to $z$ yields an expression for the geostrophic alongshelf flow:

$$
v^{g}=v^{\text {bot }}-\frac{R_{x}}{f}, \quad \text { where } \quad R_{x}=\int_{-h}^{z} \frac{g \rho_{x}}{\rho_{o}} d z^{\prime}
$$

is the cross-shelf buoyancy gradient and $v^{\text {bot }}$ is the mean alongshelf geostrophic velocity at the bottom. Assuming a linear drag law relating the mean bottom stress to the mean near-bottom velocity $\tau^{b y}=\rho_{o} r v^{\text {bot }}$ (see appendix B) and using (6),

$$
v^{\mathrm{bot}}=\frac{\tau^{b y}}{\rho_{o} r}=\frac{\tau^{s y}}{\rho_{o} r}-\frac{g h \eta_{y}}{r}-\frac{1}{r} \int_{-h}^{0} B_{y} d z .
$$

Substituting (11) into (10) and depth averaging,

$$
v^{\mathrm{da}}=\frac{\tau^{s y}}{\rho_{o} r}-\frac{g h \eta_{y}}{r}-\frac{1}{r} \int_{-h}^{0} B_{y} d z-\frac{1}{f h} \int_{-h}^{0} R_{x} d z .
$$

To simplify (12), assume constant cross-shelf and vertical density gradients in the interior, $\rho_{x}=\rho_{x}^{i}$ and $\rho_{z}=$ $\rho_{z}^{i}$, and a vertically well-mixed bottom boundary layer with $\rho_{x}=\rho_{x}^{b}$ (Fig. 2). Then 


$$
R_{x}=\left\{\begin{array}{l}
\frac{g \rho_{x}^{b}}{\rho_{o}} \delta^{b}+\frac{g \rho_{x}^{i}}{\rho_{o}}\left(z+h-\delta^{b}\right), \quad 0 \geq z \geq-h+\delta^{b} \\
\frac{g \rho_{x}^{b}}{\rho_{o}}(z+h), \quad-h+\delta^{b}>z \geq-h
\end{array} .\right.
$$

Noting that $\rho_{x}^{b}=\rho_{x}^{i}-h_{x} \rho_{z}^{i}$ for a constant thickness bottom boundary layer over a bottom with cross-shelf slope $h_{x}$ (defined as positive), and assuming $\rho_{y}$ is constant, (12) reduces to

$$
v^{\mathrm{da}}=\frac{\tau^{s y}}{\rho_{o} r}-\frac{g h \eta_{y}}{r}-\frac{g h^{2} \rho_{y}}{2 r \rho_{o}}-\frac{g h \rho_{x}^{i}}{2 f \rho_{o}}-\frac{h_{x} N^{2} \delta^{b}}{f}\left(1-\frac{\delta^{b}}{2 h}\right),
$$

where $N^{2}=-g \rho_{z}^{i} / \rho_{o}$ is the interior buoyancy frequency squared. The depth-averaged alongshelf flow is forced by the wind stress, alongshelf pressure gradient, and buoyancy gradients. The last term on the right-hand side is associated with buoyancy shutdown in the bottom boundary layer, the tendency for mixing and advection in the bottom boundary layer to establish crossisobath density gradients that reduce the near-bottom velocity and hence the bottom stress. The buoyancy shutdown term depends on the slope Burger number $h_{x} N / f$ as expected from previous theory (e.g., Trowbridge and Lentz 1991).

The contributions to $v^{\text {da }}$ in (14) exhibit different dependencies on $h$. The alongshelf wind stress term is independent of $h$, as is the buoyancy shutdown term over the mid- and outer shelf where $h \gg \delta^{b}$. The alongshelf sea surface slope and interior cross-shelf density gradient terms increase linearly with increasing $h$. The alongshelf density gradient term depends on $h^{2}$, indicating it is larger over the outer shelf.

The mean circulation in this model, given by Eqs. (5), (7), (8), and (12) or (14), is forced by the mean alongshelf wind stress, alongshelf sea surface slope, and buoyancy (density) gradients. A more complete model would solve for the density field and the alongshelf sea surface slope given atmospheric forcing, river runoff, and offshore forcing associated with the open ocean.

\section{Observations and processing}

Thirty-three MAB current-meter records longer than 200 days were found (Table 1 ). The spatial coverage is sparse and the spatial distribution is not uniform (Fig. 1 ). There are a few sites at midshelf on the southern flank of Georges Bank, a relatively large number of sites on the New England shelf, and only a few sites in the central and southern MAB. Details about the current-meter observations from each site can be found in the associated references (Table 1). Statistics for four of the sites are from Beardsley and Boicourt (1981), Butman (1987), and Biscaye et al. (1994). For the other sites, the current time series were obtained and analyzed.

"Mean" currents for each site were estimated as time averages over the duration of available data. The choice of 200 days is based on the desire to obtain mean current estimates with a standard error of the mean of $1 \mathrm{~cm} \mathrm{~s}^{-1}$ or less. The standard error of the mean, defined as $\sigma_{\text {std }} / \sqrt{n}$, is a measure of how accurately an estimate represents the true mean current. Here $\sigma_{\text {std }}$ is the standard deviation of the detided current variability and $n$ is the number of independent samples in the record. Standard deviations of detided current variability in the MAB are typically about $10 \mathrm{~cm} \mathrm{~s}^{-1}$ and decorrelation time scales are about 2 days, so record lengths of 200 days or longer are required to reduce the standard error to $1 \mathrm{~cm} \mathrm{~s}^{-1}$. This uncertainty does not account for potential bias errors in the current measurements due, for example, to improper averaging of surface gravity waves (e.g., Beardsley et al. 1981; Beardsley 1987). The uncertainty estimate also assumes there is not a large annual cycle in currents relative to the variability on time scales of days (Lentz 2008). Mean current estimates with or without removing an annual cycle are similar for the time series examined.

Depth-averaged flows are estimated using trapezoidal integration and assuming the flow is vertically uniform near the boundaries to extrapolate to the surface and bottom. Results are similar if the velocity profile is extrapolated linearly to the surface and bottom. Vertical coverage varies substantially. Acoustic Doppler current profilers (ADCPs) have sample bins every meter or less over about $80 \%$ of the water column, while there are some moorings with as few as two current meters (Table 1). Depth-average alongshelf velocities at a few sites were approximated with middepth currents because of poor data return from near-surface current meters. Depth-average alongshelf velocities at the two SEEP-I sites (Aikman et al. 1988) are approximated by $10-\mathrm{m}$ currents since these outer-shelf and upperslope sites had only near-surface and near-bottom current meters.

A coordinate system is adopted with $y$ aligned with the depth-averaged mean flow $v^{\text {da }}$, but positive poleward, and $x$ positive offshore. In this coordinate frame the depth-average mean cross-shelf velocity $u^{\text {da }}$ is zero by definition. This coordinate frame was chosen because it is consistent with the model assumptions in section 3 , and it yielded more consistent mean crossshelf flow profiles than a coordinate frame aligned with the principal axes of the subtidal depth-averaged flow. 
TABLE 1. Summary of current-meter deployments including depth-averaged alongshelf velocity $v^{\text {da }}$.

\begin{tabular}{|c|c|c|c|c|c|c|}
\hline Lat $\left({ }^{\circ} \mathrm{N}\right)$ & Lon $\left({ }^{\circ} \mathrm{W}\right)$ & $h(\mathrm{~m})$ & $\begin{array}{c}\text { No. of } \\
\text { sample depths }\end{array}$ & $\begin{array}{c}\text { Length } \\
\text { (days) }\end{array}$ & $v^{\mathrm{da}}\left(\mathrm{cm} \mathrm{s}^{-1}\right)$ & Reference \\
\hline $40^{\circ} 51.8^{\prime}$ & $67^{\circ} 33.5^{\prime}$ & 76 & 10 & 204 & -7.1 & Werner et al. (2003) \\
\hline $40^{\circ} 58.1^{\prime}$ & $67^{\circ} 19.2^{\prime}$ & 75 & 14 & 827 & -9.1 & Irish et al. (2005) \\
\hline $40^{\circ} 52.1^{\prime}$ & $67^{\circ} 24.3^{\prime}$ & 81 & 3 & 1065 & $-8.6^{*}$ & Butman (1987) \\
\hline $41^{\circ} 20.2^{\prime}$ & $70^{\circ} 33.4^{\prime}$ & 12 & 16 & 1575 & -3.1 & Fewings et al. (2008) \\
\hline $41^{\circ} 19.1^{\prime}$ & $70^{\circ} 34.2^{\prime}$ & 17 & 27 & 276 & -2.2 & Fewings et al. (2008) \\
\hline $41^{\circ} 15.3^{\prime}$ & $70^{\circ} 35.8^{\prime}$ & 27 & 20 & 372 & -5.5 & Fewings et al. (2008) \\
\hline $40^{\circ} 41.6^{\prime}$ & $70^{\circ} 8.6^{\prime}$ & 46 & 2 & 348 & $-5.0^{*}$ & Beardsley et al. (1985) \\
\hline $40^{\circ} 30.0^{\prime}$ & $70^{\circ} 12.5^{\prime}$ & 66 & 4 & 424 & $-6.1 *$ & Beardsley et al. (1985) \\
\hline $40^{\circ} 20.6^{\prime}$ & $70^{\circ} 16.1^{\prime}$ & 88 & 3 & 393 & $-7.8^{*}$ & Beardsley et al. (1985) \\
\hline $40^{\circ} 12.9^{\prime}$ & $70^{\circ} 18.2^{\prime}$ & 105 & 4 & 393 & $-9.6^{*}$ & Beardsley et al. (1985) \\
\hline $40^{\circ} 28.0^{\prime}$ & $70^{\circ} 54.7^{\prime}$ & 80 & 2 & 379 & $-6.4 * *$ & Aikman et al. (1988) \\
\hline $40^{\circ} 14.6^{\prime}$ & $70^{\circ} 55.1^{\prime}$ & 125 & 2 & 379 & $-10.2 * *$ & Aikman et al. (1988) \\
\hline $40^{\circ} 35.0^{\prime}$ & $70^{\circ} 27.5^{\prime}$ & 64 & 5 & 302 & -5.1 & Shearman and Lentz (2003) \\
\hline $40^{\circ} 29.5^{\prime}$ & $70^{\circ} 30.3^{\prime}$ & 70 & 9 & 310 & -7.6 & Shearman and Lentz (2003) \\
\hline $40^{\circ} 23.0^{\prime}$ & $70^{\circ} 32.6^{\prime}$ & 86 & 5 & 310 & -8.4 & Shearman and Lentz (2003) \\
\hline $40^{\circ} 28.5^{\prime}$ & $70^{\circ} 20.1^{\prime}$ & 70 & 4 & 310 & $-7.5^{*}$ & Shearman and Lentz (2003) \\
\hline $40^{\circ} 8.4^{\prime}$ & $70^{\circ} 6.0^{\prime}$ & 125 & 11 & 275 & -16.2 & Fratantoni and Pickart (2003) \\
\hline $40^{\circ} 0.0^{\prime}$ & $70^{\circ} 0.6^{\prime}$ & 168 & 14 & 441 & -10.5 & Fratantoni and Pickart (2003) \\
\hline $40^{\circ} 34.2^{\prime}$ & $72^{\circ} 18.5^{\prime}$ & 49 & 6 & 473 & -4.2 & Mayer (1982) \\
\hline $40^{\circ} 25.3^{\prime}$ & $72^{\circ} 8.2^{\prime}$ & 59 & 3 & 213 & -3.2 & Mayer (1982) \\
\hline $40^{\circ} 11.1^{\prime}$ & $72^{\circ} 0.2^{\prime}$ & 65 & 6 & 335 & -6.4 & Mayer (1982) \\
\hline $40^{\circ} 6.6^{\prime}$ & $72^{\circ} 55.2^{\prime}$ & 47 & 8 & 901 & -2.0 & Mayer (1982) \\
\hline $39^{\circ} 15.9^{\prime}$ & $73^{\circ} 1.4^{\prime}$ & 70 & 5 & 261 & -7.8 & Mayer (1982) \\
\hline $39^{\circ} 24.3^{\prime}$ & $73^{\circ} 43.2^{\prime}$ & 32 & 4 & 452 & -2.8 & Mayer (1982) \\
\hline $39^{\circ} 27.7^{\prime}$ & $74^{\circ} 15.7^{\prime}$ & 11 & 7 & 498 & -2.6 & Schofield et al. (2002) \\
\hline $39^{\circ} 28.0^{\prime}$ & $74^{\circ} 15.0^{\prime}$ & 12 & 2 & 1082 & -3.2 & Beardsley and Boicourt (1981) \\
\hline $38^{\circ} 43.6^{\prime}$ & $73^{\circ} 39.3^{\prime}$ & 61 & 4 & 458 & -6.5 & \\
\hline $37^{\circ} 42.0^{\prime}$ & $74^{\circ} 20.4^{\prime}$ & 90 & 15 & 399 & -8.7 & Shaw et al. (1994) \\
\hline $37^{\circ} 32.5^{\prime}$ & $74^{\circ} 26.7^{\prime}$ & 90 & 5 & 219 & -7.9 & Biscaye et al. (1994) \\
\hline $36^{\circ} 52.0^{\prime}$ & $75^{\circ} 3.0^{\prime}$ & 38 & 3 & 469 & -4.5 & Beardsley and Boicourt (1981) \\
\hline $36^{\circ} 14.7^{\prime}$ & $75^{\circ} 42.5^{\prime}$ & 22 & 2 & 536 & -6.5 & Berger et al. (1994) \\
\hline $36^{\circ} 14.7^{\prime}$ & $75^{\circ} 12.4^{\prime}$ & 35 & 3 & 461 & -3.1 & Berger et al. (1994) \\
\hline $36^{\circ} 14.6^{\prime}$ & $74^{\circ} 54.4^{\prime}$ & 60 & 3 & 560 & -6.3 & Berger et al. (1994) \\
\hline
\end{tabular}

* Mean alongshelf current at middepth rather than depth average.

** Mean alongshelf current at $10 \mathrm{~m}$ rather than depth average.

The sparse vertical coverage at many of the sites results in uncertainty in determining the orientation of the mean depth-average flow. The mean depth-average flow $v^{\text {da }}$ is oriented roughly along-isobath (Fig. 1), but is not always aligned with the principal axes of the subtidal depth-average flow. In the northern MAB, $v^{\text {da }}$ is oriented $0^{\circ}-20^{\circ}$ counterclockwise relative to the major axis orientations of the subtidal flow. The characteristics of the cross-shelf flow $u$ are sensitive to the choice of coordinate frames, while the characteristics of the alongshelf flow $v$ are not sensitive to the choice of coordinate frames.

Buoy wind observations are available at a few of the mooring locations. At current-meter sites without wind observations, the closest NDBC buoy or coastal wind observations are used (Fig. 1). In a few cases, more than one buoy wind time series is used to get a complete wind record at the site. Wind stresses are estimated from wind velocities and sensor heights using a neutral bulk formula (Large and Pond 1981).

Bottom stresses are estimated using unfiltered (hourly) near-bottom velocities and a quadratic drag law of the form $\boldsymbol{\tau}^{\mathbf{b}}=C_{D}\left(z^{\prime}\right) \mathbf{u}\left(z^{\prime}\right)\left|\mathbf{u}\left(z^{\prime}\right)\right|$. The magnitude and dependence of the drag coefficient $C_{D}$ on height above the bottom $z^{\prime}=h-z$ is determined empirically from near-bed covariance stress observations over Georges Bank (see appendix B). From the Georges Bank estimates, $C_{D} \approx 0.001$ at $5 \mathrm{~m}$ above the bottom. Comparisons with covariance stress estimates from two other sites suggest an uncertainty of about $50 \%$ (appendix B).

Mean cross-shelf and along-isobath density gradients are estimated using density profiles from the National Oceanographic Data Center's World Ocean Database 2001 archive of ship observations. The observations were quality controlled and water depths were deter- 
mined using the National Geophysical Data Center high-resolution bathymetry for the region (Lentz et al. 2003). A total of 20158 profiles over the shelf (water depth $\leq 100 \mathrm{~m}$ ) were extracted, excluding profiles in Chesapeake Bay, Delaware Bay, Long Island Sound, Buzzards Bay, and Nantucket Sound. Each shelf profile was interpolated onto a 5-m vertical grid.

The mean density gradients along the 30-, 50-, 70-, and $90-\mathrm{m}$ isobaths are estimated by finding all profiles in a 20-m depth band around a given isobath, for example, between the 60- and 80-m isobaths for estimates along the $70-\mathrm{m}$ isobath. An average annual cycle is removed to minimize biases associated with uneven seasonal sampling. Mean along-isobath trends are estimated at each 5-m depth interval. The mean depthaveraged $\rho_{y} \approx 0\left(\mathrm{~kg} \mathrm{~m}^{-3}\right) \mathrm{m}^{-1}$ to the accuracy of the trend estimates and exhibits no clear alongshelf variations. Below 20-m depth, $\rho_{y} \approx 1-2 \times 10^{-7}\left(\mathrm{~kg} \mathrm{~m}^{-3}\right)$ $\mathrm{m}^{-1}$, about the same size as the $95 \%$ confidence bounds for the trend estimate. At the surface there is a slightly larger $\rho_{y}$ of the opposite sign.

To estimate the mean cross-shelf density gradient $\rho_{x}$, the minimum distance to the $100-\mathrm{m}$ isobath is determined for each density profile, an average annual cycle is removed, and the cross-shelf trend is estimated for all profiles between the $20-$ and $100-\mathrm{m}$ isobaths. The estimated mean cross-shelf density gradient is $\rho_{x} \approx 4 \times$ $10^{-6}\left(\mathrm{~kg} \mathrm{~m}^{-3}\right) \mathrm{m}^{-1}$, which is significantly different from zero at the $95 \%$ confidence level. Estimates are slightly higher near the surface and bottom $\left[5-6 \times 10^{-6}(\mathrm{~kg}\right.$ $\left.\left.\mathrm{m}^{-3}\right) \mathrm{m}^{-1}\right]$ and slightly lower at middepth $\left[3 \times 10^{-6}(\mathrm{~kg}\right.$ $\left.\mathrm{m}^{-3}\right) \mathrm{m}^{-1}$. Estimates of $\rho_{x}$ are essentially the same for different subsets of the data, that is, the New England shelf or southern and central MAB.

\section{Results}

\section{a. Alongshelf mean flow}

Consistent with previous studies (e.g., Beardsley et al. 1976; Pietrafesa et al. 2002), depth-average mean currents at all sites over the MAB shelf are equatorward and approximately along-isobath (Fig. 1; Table 1). The exception to this is the flow within Hudson shelf valley, the only canyon that extends across the entire MAB shelf. Hudson shelf valley has a dramatic influence on the local circulation, with mean along-valley flows that are onshore at $5-10 \mathrm{~cm} \mathrm{~s}^{-1}$ (Nelsen et al. 1978; Mayer 1982; Manning et al. 1994; Harris et al. 2003). The subsequent analysis does not include the current observations from the two sites within Hudson shelf valley.

Depth-average mean alongshelf currents $v^{\text {da }}$ increase with increasing water depth $h$ over the shelf $(h \leq 120)$

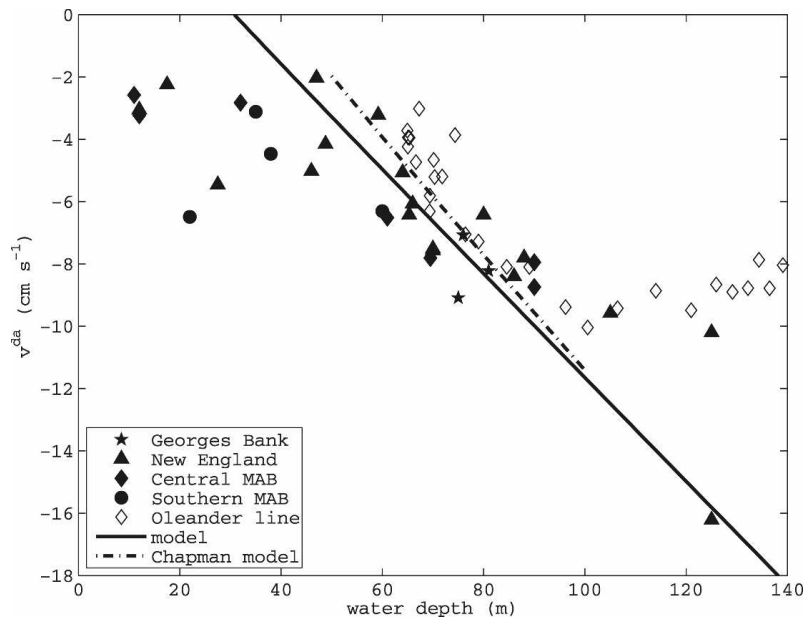

FIG. 3. Mean depth-averaged alongshelf flow $v^{\text {da }}$ as a function of water depth $h$. Predicted $v^{\text {da }}$ dependence on $h$ from the model developed in section 3 (solid line, the model is not valid onshore of $30-\mathrm{m}$ isobath) and from the model of Chapman and Lentz (2005) (dash-dot line) discussed in section 6b.

from $-3 \mathrm{~cm} \mathrm{~s}^{-1}$ in $15-\mathrm{m}$ water depth to $-10 \mathrm{~cm} \mathrm{~s}^{-1}$ in 100-m water depth (Fig. 3). The correlation between $h$ and $v^{\text {da }}$ over the shelf is -0.83 (significantly different from zero at the $99 \%$ confidence level), with a regression slope of $-0.07 \pm 0.02 \mathrm{~cm} \mathrm{~s}^{-1} \mathrm{~m}^{-1}$ and an intercept of $-1.8 \pm 1.2 \mathrm{~cm} \mathrm{~s}^{-1}$. The most notable outlier over the shelf is from a site near the coast (water depth $20 \mathrm{~m}$ ), south of Chesapeake Bay, where there is an enhanced southward flow that is probably associated with the buoyant coastal current from Chesapeake Bay (Rennie et al. 1999). Observations of $v^{\text {da }}$ from repeated shipboard ADCP transects along the Oleander line (Flagg et al. 2006) show more scatter than the moored observations in the depth range from 65 to $75 \mathrm{~m}$ because the Oleander line passes over Hudson shelf valley in this depth range (Fig. 1). The consistency of the relationship between $h$ and $v^{\text {da }}$ over the MAB shelf suggests the mean currents do not vary substantially along isobath between Georges Bank and Cape Hatteras, though the spatial coverage is sparse (Fig. 1). The consistency of the relationship also suggests interannual variations over the last few decades are small, typically $1-2 \mathrm{~cm} \mathrm{~s}^{-1}$ or less, since the means span different time periods.

It is interesting that the shelfbreak jet does not stand out in the mean depth-averaged flow. In particular, $v^{\mathrm{da}}$ from two sites near the shelf break in the mid- and southern MAB (Fig. 1), where the shelf break is shallower, exhibit the same dependence on $h$. Over the upper slope, between the 100- and $150-\mathrm{m}$ isobaths, $v^{\mathrm{da}}$ remains about $-10 \mathrm{~cm} \mathrm{~s}^{-1}$, though the uncertainties in the mean are much larger because the decorrelation time scales are longer due to features such as warm- 


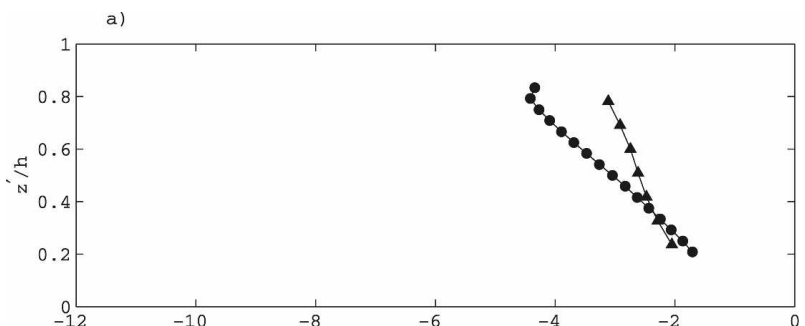

b)

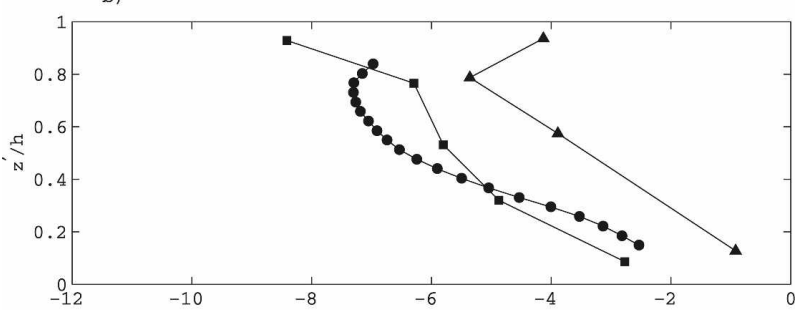

c)

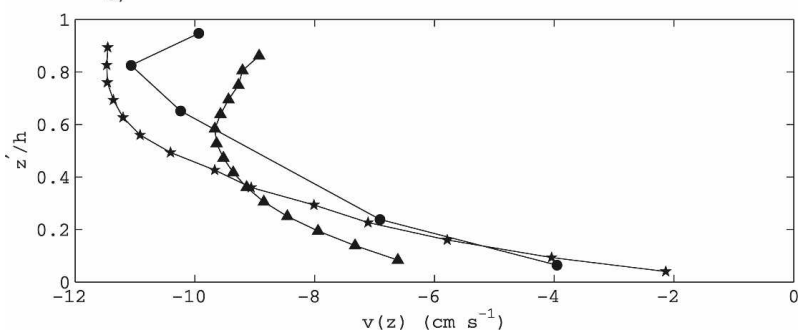

FIG. 4. Examples of mean alongshelf velocity profiles $v\left(z^{\prime}\right)$ vs normalized height $z^{\prime} / h$ : (a) New England ( $h=12 \mathrm{~m}$; circle) and New Jersey ( $h=15 \mathrm{~m}$; triangle); (b) New England ( $h=27 \mathrm{~m}$, circle), New England ( $h=64 \mathrm{~m}$; square), near Hudson shelf valley ( $h=47 \mathrm{~m}$; triangle); (c) Georges Bank ( $h=75 \mathrm{~m}$; star), New England ( $h=86 \mathrm{~m}$; square), central MAB ( $h=90 \mathrm{~m}$; triangle).

core rings (Fratantoni and Pickart 2003; Flagg et al. 2006).

Mean wind stresses are generally southeastward (offshore), opposing the mean flow in the northern MAB, perpendicular to the mean flow in the central MAB and the southern flank of Georges Bank, and partially in the direction of the mean flow in the southern MAB (Fig. 1). The depth-average mean alongshelf currents in the absence of wind forcing were estimated as the intercepts of a linear regression between the wind stress and $v^{\text {da }}$ for the temporal lag and wind stress orientation that yielded the maximum correlation between $\tau^{s}$ and $v^{\mathrm{da}}$. The intercept estimates of the depth-average mean alongshelf currents in the absence of wind forcing (not shown) are similar to $v^{\text {da }}$ and exhibit the same dependence on water depth (correlation -0.80 and regression slope $\left.-0.08 \pm 0.02 \mathrm{~cm} \mathrm{~s}^{-1} \mathrm{~m}^{-1}\right)$, indicating $v^{\text {da }}$ is not primarily driven by the local wind stress (see section $5 \mathrm{c}$ ).

The alongshelf velocity $v(z)$ increases with height above the bottom except near the surface (Fig. 4). The

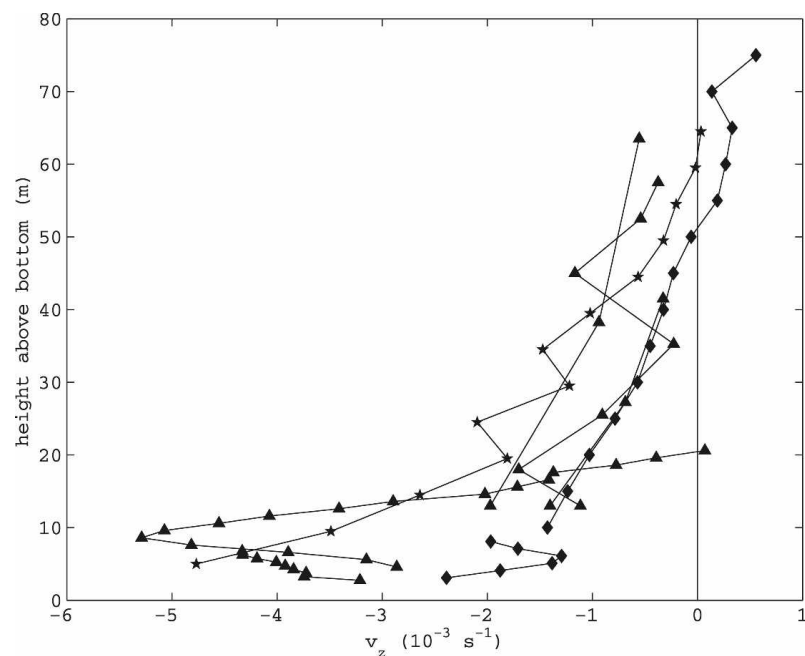

FIG. 5. The mean vertical shear in the alongshelf flow $v_{z}$ as a function of height above the bottom for various mooring sites over the MAB shelf.

profiles tend to be linear over the inner shelf and curved over the mid- to outer shelf with stronger vertical shear in the lower half of the water column. Vertical shears are $2-4 \times 10^{-3} \mathrm{~s}^{-1}$ near the bottom at all water depths, decrease with height, and are near zero more than $50 \mathrm{~m}$ above the bottom (Fig. 5).

\section{b. Cross-shelf mean flow}

In this coordinate frame, where $u^{\mathrm{da}}=0$, there is a consistent vertical and cross-shelf structure to the mean cross-shelf flow $u(z)$ (Fig. 6). Over the inner shelf (water depths 10-15 m), there is a two-layer structure with offshore flow of $1 \mathrm{~cm} \mathrm{~s}^{-1}$ near the surface and onshore flow of $1 \mathrm{~cm} \mathrm{~s}^{-1}$ near the bottom (Fig. 6a) (see also Codiga 2005). Over the midshelf, there is offshore flow (1-3 $\left.\mathrm{cm} \mathrm{s}^{-1}\right)$ near the surface, maximum onshore flow of $\sim 0.5 \mathrm{~cm} \mathrm{~s}^{-1}$ at middepth and generally weak crossshelf flow near the bottom (Fig. 6b). Over the outer shelf, there is offshore flow $\left(0-4 \mathrm{~cm} \mathrm{~s}^{-1}\right)$ near the surface, maximum onshore flow of $0.5-1 \mathrm{~cm} \mathrm{~s}^{-1}$ at middepth, and offshore flow of $1 \mathrm{~cm} \mathrm{~s}^{-1}$ near the bottom (Fig. 6c).

Near-surface cross-shelf flows $\left(u^{s}\right)$ are variable with a tendency for stronger offshore flows in the northern MAB and weaker cross-shelf flows in the southern MAB ( $\bigcirc$ in Fig. 7). The maximum onshore "interior" flow $\left(u^{i}\right)$ at each site (• in Fig. 7) is remarkably consistent, ranging between -0.2 and $-1.4 \mathrm{~cm} \mathrm{~s}^{-1}$, except at one of the southern sites where $u^{i} \approx 0.2 \mathrm{~cm} \mathrm{~s}^{-1}$ (alongshelf distance $-1300 \mathrm{~km}$ in Fig. 7). The onshore interior flow compensates for the near-surface and near-bottom (discussed below) offshore flows and is also consistent with an alongshelf pressure gradient (higher pressure to 


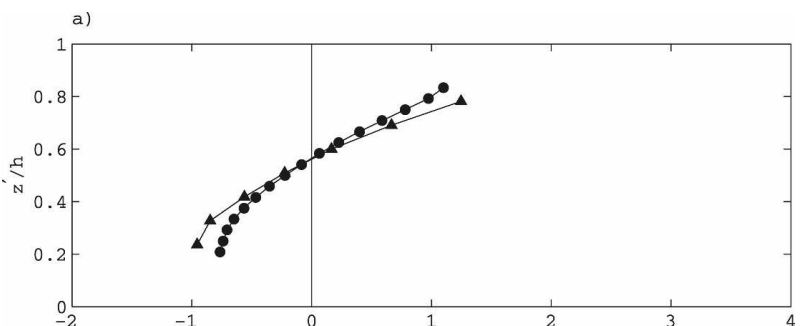

b)
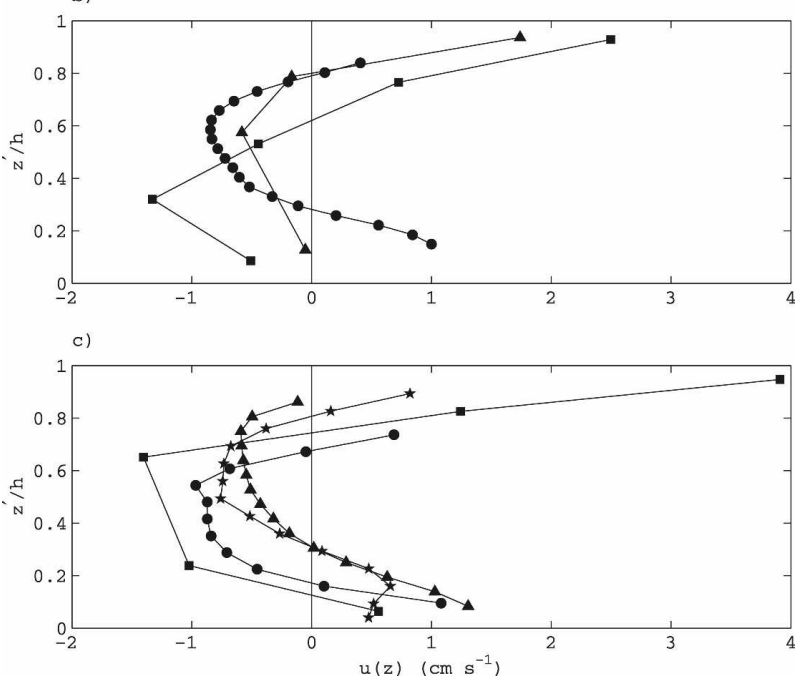

FIG. 6. Examples of mean cross-shelf velocity profiles $u\left(z^{\prime}\right)$ vs normalized height $z^{\prime} / h$ : (a) New England ( $h=12 \mathrm{~m}$; circle) and New Jersey ( $h=15 \mathrm{~m}$; triangle); (b) New England ( $h=27 \mathrm{~m}$, circle), New England ( $h=64 \mathrm{~m}$; square), near Hudson shelf valley ( $h=47 \mathrm{~m}$; triangle); (c) Georges Bank ( $h=75 \mathrm{~m}$; star), New England ( $h=86 \mathrm{~m}$; square), New England ( $h=125 \mathrm{~m}$; circle), central MAB $(h=90 \mathrm{~m}$; triangle).

the north) and a geostrophic interior as discussed below. Neither the near-surface flow nor the maximum onshore flow exhibit any obvious dependence on water depth (not shown).

In contrast, near-bottom cross-isobath flows $\left(u^{b}\right)$ tend to increase linearly with water depth from -1 $\mathrm{cm} \mathrm{s}^{-1}$ (onshore) in shallow water to $\sim 4 \mathrm{~cm} \mathrm{~s}^{-1}$ (offshore) at the $250-\mathrm{m}$ isobath (Fig. 8). The correlation between $h$ and $u^{b}$ is 0.78 and the regression slope is $0.018 \pm 0.004 \mathrm{~cm} \mathrm{~s}^{-1} \mathrm{~m}^{-1}$. Farther seaward over the slope, the near-bottom offshore flow decreases to 1-2 $\mathrm{cm} \mathrm{s}^{-1}$. Figure 8 includes observations summarized in two previous studies of near-bottom flow over the MAB shelf and slope (Butman 1987; Csanady et al. 1988). The observations of $u^{b}$ support Bumpus' (1965) conclusion from bottom drifter returns that the nearbottom flow is onshore shoreward of the $60-\mathrm{m}$ isobath and offshore seaward of the $60-\mathrm{m}$ isobath. Mean nearbottom cross-shelf flows near the mouth of Delaware Bay are also onshore at about $1 \mathrm{~cm} \mathrm{~s}^{-1}$ (Pape and Gar-

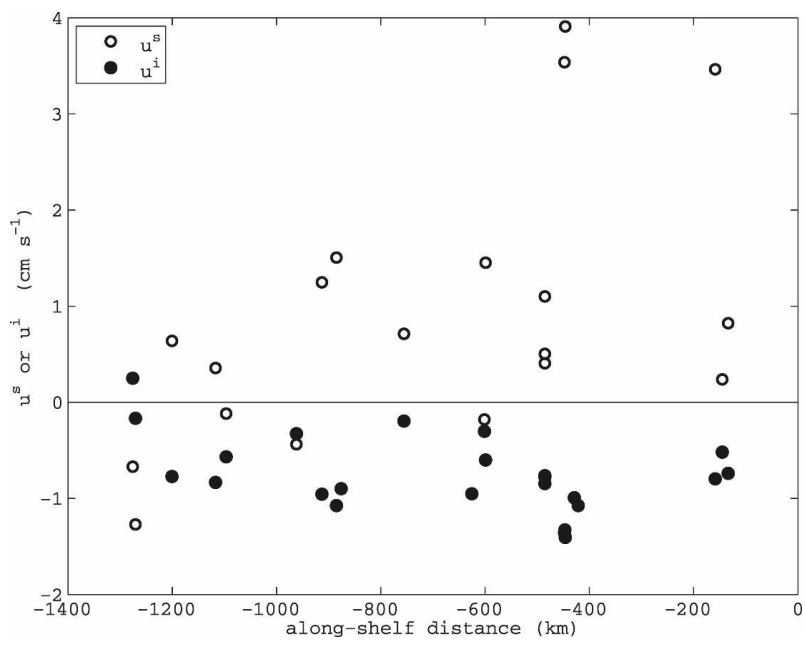

FIG. 7. Near-surface $u^{s}(\bigcirc)$ and "interior" $u^{i}(\bullet)$ cross-shelf velocities as a function of along-isobath distance from northeastern Georges Bank $(0 \mathrm{~km})$ to Cape Hatteras $(-1400 \mathrm{~km})$. Near-surface mean velocities are from shallowest current measurement within $20 \mathrm{~m}$ of the surface at each site. Interior velocities are maximum onshore mean flow at each site.

vine 1982; Garvine 1991). The moored currents indicate that $u^{b}$ crosses zero at about the $50-\mathrm{m}$ isobath.

The observed cross-shelf circulation pattern is summarized in Fig. 2. Over the mid-and outer shelf there is an offshore flow near the surface, onshore flow in the interior, and offshore flow near the bottom. Over the inner shelf, there is offshore flow near the surface and onshore flow near the bottom. The near-bottom flow increases linearly with distance offshore from the inner

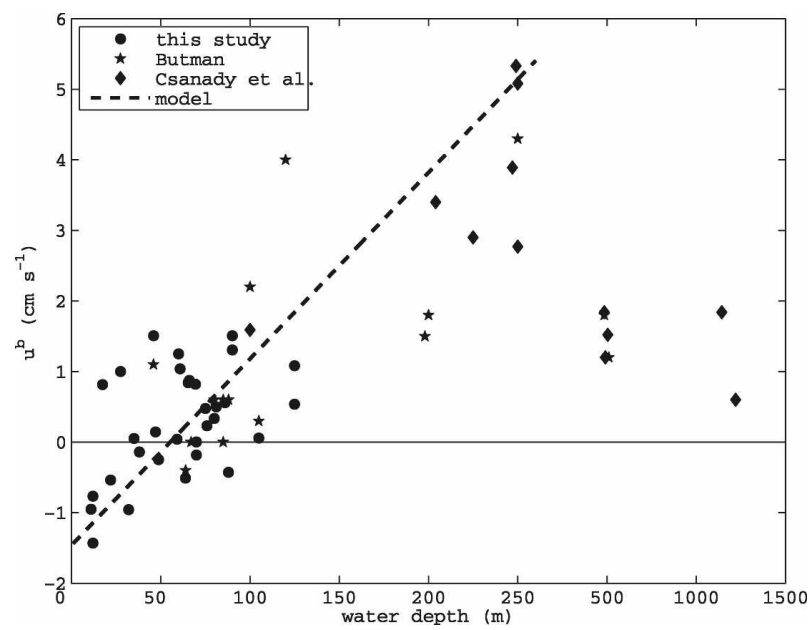

FIG. 8. Near-bottom cross-shelf velocity $u^{b}$ as a function of water depth. Additional observations from Butman (1987) and Csanady et al. (1988) for time series longer than 100 days. Note change in water depth scale for $h>250 \mathrm{~m}$. Near-bottom currents are deepest current measurement within $20 \mathrm{~m}$ of the bottom at each site. 

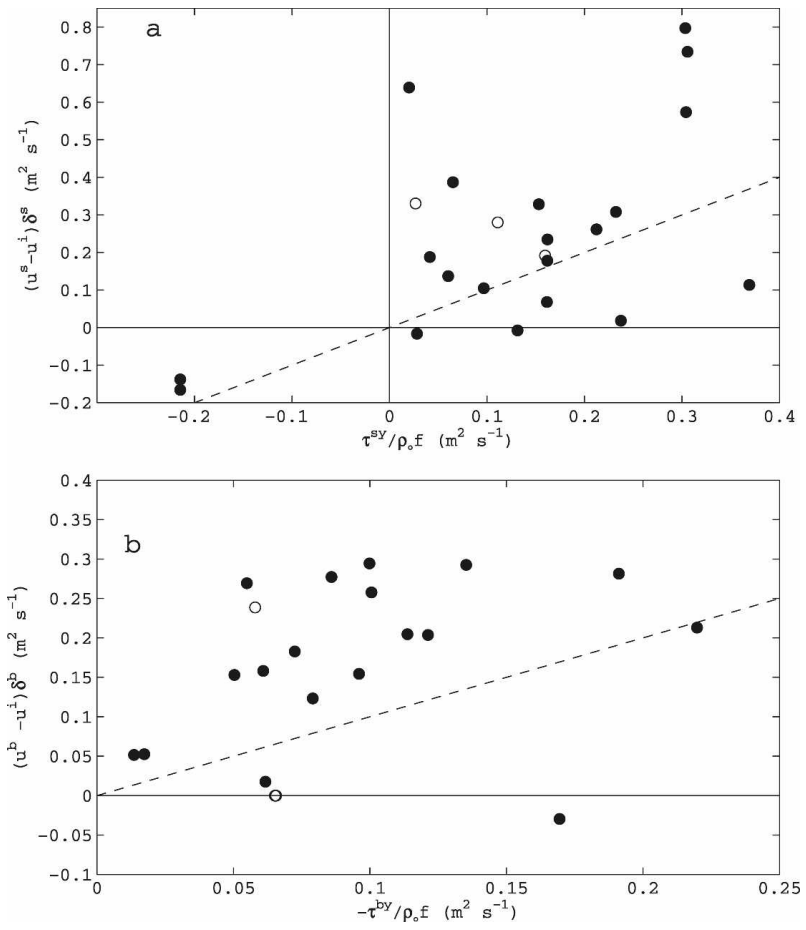

FIG. 9. Estimates of (a) near-surface $U^{s} \approx\left(u^{s}-u^{i}\right) \delta^{s}$ and (b) near-bottom $U^{b} \approx\left(u^{b}-u^{i}\right) \delta^{b}$ cross-shelf transport relative to interior velocity vs associated Ekman transports $\tau^{s y} / \rho_{o} f$ and $\tau^{b y} / \rho_{o} f$. Open circles are inner-shelf sites, $h \leq 20 \mathrm{~m}$.

shelf to the upper slope. While the mean cross-shelf velocities (Figs. 6, 7, and 8) are similar in magnitude to the accuracy of the current measurements, the consistency of the circulation pattern suggests they are real.

\section{c. Comparison of model and observations}

The model developed in section 3 provides estimates of $v^{\text {da }}$ from [(12) or (14)], $u^{s}$ from (7), $u^{b}$ from (8), and $u^{i}=u^{g}$ from (5) given $h, h_{x}, f, N, \delta^{s}, \delta^{b}, r$, and the forcing terms: the wind stress, the alongshelf sea surface slope, and the buoyancy (density) gradients. In this section, model estimates are compared to the observed mean flow.

First, the proposed mean Ekman balances (4) are evaluated by comparing the alongshelf surface (bottom) Ekman transport estimates based on the surface (bottom) stress at each site to rough estimates of the near-surface (near bottom) cross-shelf transport deficit $\left(u^{s}-u^{i}\right) \delta^{s}\left[\left(u^{b}-u^{i}\right) \delta^{b}\right]$ at each site. Assuming constant boundary layer thicknesses $\delta^{s}=\delta^{b}=15 \mathrm{~m}$ based on the observed mean cross-shelf current profiles (Fig. 6), there is reasonable agreement between the two terms in the Ekman balances for both the surface and bottom boundary layers (Fig. 9). For the surface layer, the correlation is 0.52 and the regression slope is $0.9 \pm 0.7$. For the bottom layer, the correlation is 0.37 . However, if the two sites south of Chesapeake Bay are excluded (two of the points below dashed line in Fig. 9b), the correlation is 0.66 and the regression slope is $1.4 \pm 0.8$. The two sites south of Chesapeake Bay have only three current meters spanning the water column and do not exhibit the same vertical structure seen at the other sites. Between Chesapeake Bay and Cape Hatteras there is also a tendency for the mean flow to turn offshore (Pietrafesa et al. 2002), which may influence these relationships. This evaluation is crude and is only intended to show there is a rough relationship between Ekman and observed transports. A more careful analysis would integrate currents over a variable boundary layer thickness, but the necessary observations are not available at most of the sites.

For simplicity, mean values of $\tau^{s y}, \tau^{s x}, \eta_{y}, \rho_{x}, \rho_{y}, \delta^{s}=$ $15 \mathrm{~m}, \delta^{b}=15 \mathrm{~m}, h_{x}=6 \times 10^{-4}, N$, and $r$ are all assumed to be spatially uniform. In reality, each of these inputs may vary both across the shelf and along the shelf. A linear resistance coefficient of $r=2.5 \times 10^{-4} \mathrm{~m} \mathrm{~s}^{-1}$ is used based on comparisons of $r \mathbf{u}^{\mathbf{b}}$ and the mean bottom stresses $\tau^{\mathbf{b}}$ (appendix B). The magnitude of $r$ depends on the $C_{D}$ profile, which is uncertain. The mean wind stress in the coordinate frame of the mean depthaveraged current is estimated as the average of the wind stresses from the various sites, $\tau^{s x}=0.013 \mathrm{~N} \mathrm{~m}^{-2}$ and $\tau^{s y}=0.015 \mathrm{~N} \mathrm{~m}^{-2}$. The mean density gradients estimated from the density profiles in the National Oceanographic Data Center (NODC) historical hydrographic database (section 4) are $\rho_{x}=4 \times 10^{-6} \mathrm{~kg} \mathrm{~m}^{-4}$ and $\rho_{y}=0 \mathrm{~kg} \mathrm{~m}^{-4}$, and the mean buoyancy frequency is $N=0.01 \mathrm{~s}^{-1}$.

Reliable direct estimates of the mean alongshelf pressure gradient do not exist. However, Eqs. (5) and (6) provide two independent estimates of $P_{y}=\rho_{o} g \eta_{y}$ (since $\rho_{y}=0$ and therefore $B_{y}=0$ ). The two estimates of $P_{y}$ are correlated (Fig. 10) except for the three sites in less than $20 \mathrm{~m}$ of water where one does not expect a geostrophic interior (Fig. 6a).

For the 19 sites where $h>15 \mathrm{~m}$, the correlation between $-f u^{i}$ and $\left(\tau^{s y}-\tau^{b y}\right) / \rho_{o} h$ is 0.71 , significantly different from zero at the $99 \%$ confidence level. The agreement is remarkable given that the measured $u^{i}$ s (less than $1.5 \mathrm{~cm} \mathrm{~s}^{-1}$; Fig. 7) are the same magnitude as the uncertainty in the current measurements and uncertainties in the stress estimates are also relatively large. The $-f u^{i}$ estimates are about 1.6 times larger than the $\left(\tau^{s y}-\tau^{b y}\right) / \rho_{o} h$ estimates, corresponding to an onshore velocity discrepancy of $0.5 \mathrm{~cm} \mathrm{~s}^{-1}$ or less. The discrepancy is too large to be accounted for by uncertainties in the estimate of $B_{y}$ and adjusting the bottom drag coefficient does not improve the comparison. The 


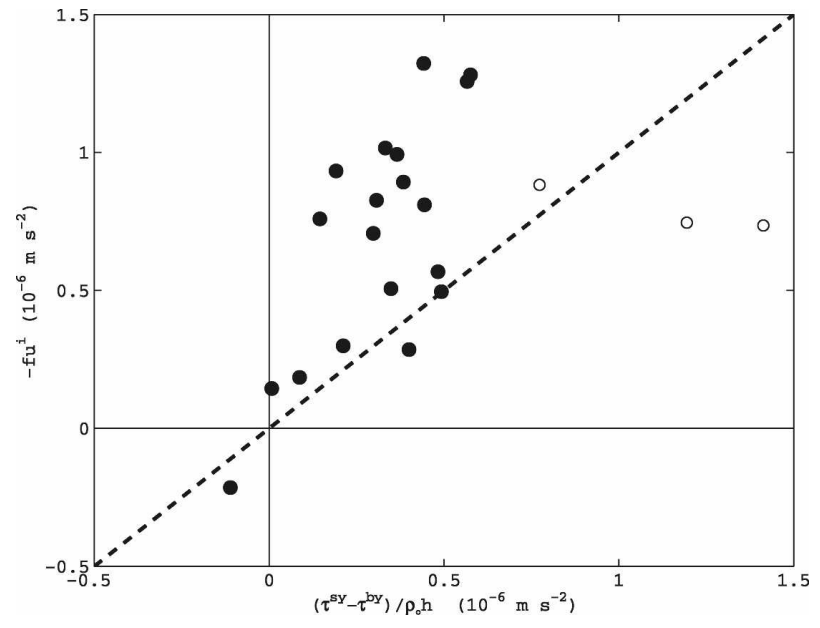

FIG. 10. Comparison of two estimates of the alongshelf pressure gradient $-f u^{i}$ assuming interior geostrophic balance and $\left(\tau^{s y}-\right.$ $\left.\tau^{b y}\right) / \rho_{o} h$ from the depth-averaged alongshelf momentum balance. Open circles are inner-shelf sites, $h \leq 20 \mathrm{~m}$.

discrepancy could be due to a bias in the bulk wind stress estimates or bias errors in the mean interior cross-shelf currents. The smaller alongshelf pressure gradients estimated from the surface and bottom stresses are more consistent with the observed depthaveraged alongshelf velocity and the near-bottom cross-shelf velocity than pressure gradient estimates based on the interior cross-shelf currents (see below). This suggests the cross-shelf interior currents are overestimated, possibly due to wave-bias errors (Beardsley et al. 1981; Beardsley 1987).

The pressure gradient estimates decrease toward zero in the region south of Chesapeake Bay (evident from $u^{i}$ in Fig. 7), as suggested by Bush and Kupferman (1980). This is qualitatively consistent with the tendency for the shelf flow to turn offshore between Chesapeake Bay and Cape Hatteras (Pietrafesa et al. 2002; Gawarkiewicz and Linder 2006). The average of the $\left(\tau^{s y}-\tau^{b y}\right) / \rho_{o} h$ estimates north of Chesapeake Bay and offshore of the $15-\mathrm{m}$ isobath yield a mean alongshelf sea surface slope $\eta_{y}$ of $3.7 \times 10^{-8}$ (sea surface elevation increasing poleward). The average estimate of $\eta_{y}$ based on the $-f u^{i}$ estimates is $7.8 \times 10^{-8}$. The inner-shelf estimates of $\left(\tau^{s y}-\tau^{b y}\right) / \rho_{o} h$ are relatively large, suggesting a larger $\eta_{y}$ near the coast. Interestingly, the estimate of $\eta_{y}$ from $\left(\tau^{s y}-\tau^{b y}\right) / \rho_{o} h$ for the inner shelf south of Martha's Vineyard is the same as the widely quoted estimate of $1.4 \times 10^{-7}$ by Scott and Csanady (1976) from the inner shelf south of Long Island. The larger inferred pressure gradient may be associated with the coastal geometry since both sites are located offshore of islands, or there may be an enhanced alongshelf pressure gradient over the inner shelf due, for example, to buoyant gravity currents (e.g., Rennie et al. 1999).

Accurate measurement of the implied alongshelf pressure gradient is challenging, as it requires measuring the sea surface slope relative to the geoid with an accuracy of better than $1 \mathrm{~cm}$ over $1000 \mathrm{~km}$. Additionally, one must separate the mean alongshelf pressure gradient $\eta_{y}$ from the larger mean cross-shelf pressure gradient $\eta_{x}$. In the following, a mean sea surface slope of $\eta_{y}=3.7 \times 10^{-8}$ is assumed based on the stress estimates and the depth-averaged alongshelf momentum balance (6).

Model estimates of $u^{b}$ from (8) using the values of $\tau^{s y}$, $\eta_{y}$, and $\delta^{b}$ given above are in quantitative agreement with the observations of $u^{b}$ (Fig. 8, dashed line). In particular, the model predicts a linear increase in $u^{b}$ with increasing water depth $h$, onshore near-bottom flow shoreward of the 50-m isobath, and approximately the correct magnitude for the near-bottom flow out to the $250-\mathrm{m}$ isobath. The agreement between the observed and modeled $u^{b}$ provides further support for the magnitude of the inferred alongshelf pressure gradient, as previously noted by Csanady (1976), and suggests $P_{y}$ is roughly constant out to the $250-\mathrm{m}$ isobath. The model also provides a simple dynamical explanation for the reversal in $u^{b}$ at about the 50-m isobath. If $P_{y}$ does not vary across the shelf, as assumed, then from (5) the onshore interior velocity $u^{g}$ is also constant. However, from (6), $\tau^{b y}$ must increase as the water depth increases to balance $P_{y} h$ (assuming $\tau^{s y}$ is approximately constant) because the pressure gradient is a body force. This implies the offshore Ekman velocity $u^{b e}=\tau^{b y} /\left(\rho_{o} f \delta^{b}\right)$ increases with water depth. At about the $50-\mathrm{m}$ isobath $u^{b e} \approx-u^{g}$ so $u^{b} \approx 0$. The isobath where $u^{b}$ changes sign may be estimated from (8) by setting $u^{b}=0$ and solving for $h$. The resulting expression for the isobath where $u^{b}$ reverses is

$$
h^{b r}=\delta^{b}+\frac{\tau^{s y}}{\rho_{o} g \eta_{y}},
$$

which for the model inputs used yields $h^{b r}=55 \mathrm{~m}$. Thus, onshore of the 55-m isobath $u^{b e}<-u^{g}$, while offshore of the 55-m isobath $u^{b e}>-u^{g}$.

Model estimates of $v^{\text {da }}$ from (12) are also in reasonable agreement with the observations for water depths between the 50- and 100-m isobaths (Fig. 3). Over the inner shelf, where the model is not valid because $h \leq$ $\delta^{s}+\delta^{b}$, model estimates of $v^{\text {da }}$ (dashed line in Fig. 3) are closer to zero than the observed flow. Stronger cross-shelf and alongshelf buoyancy forcing associated with local river discharges (e.g., Munchow and Garvine 1993; Rennie et al. 1999; Munchow and Chant 2000; Ullman and Codiga 2004), the steeper bottom slope 


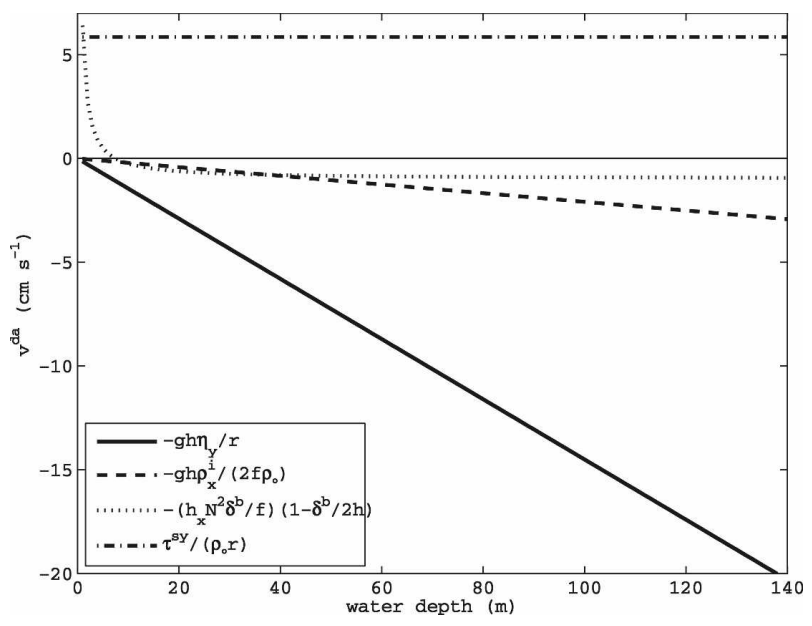

FIG. 11. Contributions of the mean alongshelf pressure gradient, two cross-shelf buoyancy force terms, and alongshelf wind stress to the mean depth-averaged flow (12). Forcing terms are all assumed to be spatially uniform, $\tau^{s y}=0.015 \mathrm{~N} \mathrm{~m}^{-2}, \eta_{y}=3.7 \times$ $10^{-8}$, and $\rho_{x}^{i}=4 \times 10^{-6} \mathrm{~kg} \mathrm{~m}^{-4}$.

over the inner shelf, the influence of cross-shelf winds (Fewings et al. 2008) and/or surface waves (Lentz et al. 2008), and weaker mean alongshelf wind stresses near the coast (Saunders 1977; Fig. 1) may all influence the inner-shelf response.

The contributions of the four forcing terms to $v^{\text {da }}$ in (14) indicate that the alongshelf pressure gradient dominates the response and primarily accounts for the linear increase of $v^{\mathrm{da}}$ with $h$ over the mid- and outer shelf (Fig. 11). The alongshelf wind stress drives an opposing mean flow. The cross-shelf buoyancy force contribution from the interior cross-shelf density gradient is about a factor-of- 8 smaller than the alongshelf pressure gradient term, although as noted above, the cross-shelf buoyancy force may be more important over the inner shelf. The last term in (14), associated with buoyancy shutdown in the bottom boundary layer (dotted line in Fig. 11), is approximately constant over the mid- and outer shelf and also relatively small compared to the pressure gradient, consistent with the small slope Burger number $\left(h_{x} N / f=0.06\right)$ characterizing the MAB mid- and outer shelf.

\section{Discussion}

While the observations examined here provide a remarkably consistent picture of the MAB mean circulation, several limitations in both the observations and model are evident. The spatial coverage of the current observations is sparse and uneven. As a result, the mean circulation picture may be biased toward conditions on the New England shelf. Direct measurements of the mean alongshelf pressure gradient are a key missing element in testing the proposed model. However, given the estimated size of the sea surface slope, the difficulty of making accurate mean pressure measurements, and the uncertainty in the reference geoid, obtaining an accurate estimate of the mean pressure gradient seems problematic. Another large uncertainty in the present analysis is bottom stress. More covariance estimates of near-bottom stress are needed. Existing estimates (appendix B) are inconsistent with log profile estimates, even relatively close to the bottom, suggesting this may not be an effective way to estimate the bottom stress over the MAB shelf.

The model developed in section 3 is incomplete in the sense that both the alongshelf pressure gradient and the cross-shelf density gradient are prescribed as forcings, although they are clearly part of the larger-scale response (e.g., Beardsley and Winant 1979). Numerical models with more complete physics may provide the needed insight into the dynamics associated with establishment of both the alongshelf pressure gradient and the cross-shelf density structure. Brief discussions of these two terms are given below, followed by estimates of the alongshelf transports.

\section{a. Alongshelf pressure gradient}

As noted in section 2, the alongshelf pressure gradient has been attributed to either the alongshelf buoyancy forcing associated with coastal runoff or the larger-scale ocean circulation. The mean depthaveraged along-isobath density gradient over the MAB shelf determined from the archived hydrographic profiles is zero to the accuracy of the estimate and does not drive the mean alongshelf flow, in support of Stommel and Leetmaa's (1972) results. The agreement between the observations and model estimates of $v^{\mathrm{da}}$ and $u^{b}$ also suggest an alongshelf pressure gradient that does not vary across the shelf. These results are consistent with model results that indicate a pressure gradient imposed by the large-scale circulation would not vary across the shelf (Csanady 1978; Beardsley and Winant 1979), but it remains unclear how such a pressure gradient would penetrate onto the shelf (Wang 1982; Chapman et al. 1986). The observed flow may also be the result of an upstream volume transport onto the shelf associated with flow from the Arctic and Hudson Strait that no longer has a significant alongshelf buoyancy gradient.

Though an alongshelf pressure gradient forcing has been assumed here and in previous studies, the observations are consistent with any body force that is spatially uniform and has the magnitude of the estimated pressure gradient. In particular, the observed mean flows could be forced by eddy variability as characterized in studies using statistical mechanics to parameter- 
ize eddy forcing (e.g., Holloway 1992; Merryfield et al. 2001) or by variable flow over rough bathymetry (Haidvogel and Brink 1986; Samelson and Allen 1987). Both these models predict mean flows in the same direction as observed. However, at present it is difficult to evaluate these models using oceanic observations because the models do not provide characterizations of the mean flow in terms of clearly defined observable variables and generally do not consider forced-dissipative systems or stratification. For variable flow over rough bathymetry assuming topographic bumps with a height of $5 \mathrm{~m}$, estimates of the mean flow magnitude from both the theory [Eq. (5.1) in Samelson and Allen 1987] and the numerical model results (Haidvogel and Brink 1986) are about an order of magnitude smaller than the observed mean alongshelf flow. A simple estimate proposed by Merryfield et al. (2001) for an eddy forced, barotropic mean flow is

$$
v=-\frac{f L^{2} h_{x}}{h},
$$

where $L$ is an eddy length scale. If $L$ is constant, then $v$ is inversely proportional to $h$, which is not what is observed in Fig. 3. However, assuming $L \approx N h / f$ is proportional to the baroclinic deformation radius yields

$$
v=-\frac{\mathrm{N}^{2} h_{x}}{f} h=-6.7 \times 10^{-4} h,
$$

for $N=10^{-2} \mathrm{~s}^{-1}, f=0.9 \times 10^{-4} \mathrm{~s}^{-1}$, and $h_{x}=6 \times 10^{-4}$. This is remarkably close to the observed relationship, suggesting eddy variability is a plausible forcing mechanism that warrants further attention.

\section{b. Cross-shelf density gradient}

The cross-shelf density gradient is primarily due to the cross-shelf salinity variation from relatively salty open-ocean water to fresher water near the coast resulting from the tendency for freshwater discharge from rivers and estuaries to turn and flow alongshelf as narrow buoyant gravity currents. The mean cross-shelf distribution of density presumably depends on vertical and lateral mixing, but the specific process(es) are not clear. Wind forcing, tidal mixing, and instabilities are likely processes. A model proposed by Chapman and Lentz (2005) is based on the idea that the basic mechanism for establishing the cross-shelf density gradient is buoyancy advection and vertical mixing within the bottom boundary layer. The Chapman and Lentz model solves the same momentum equations as in section 3 , but includes a density equation and hence solves for the cross-shelf density structure assuming an initial stratification. The bottom boundary layer is assumed to be vertically mixed in density. Lateral density gradients form because of the sloping bottom, the interior stratification, and cross-isobath advection in the bottom boundary layer. Consequently, there is a vertically sheared alongshelf flow in thermal wind balance with the crossisobath density gradients in the bottom boundary layer that reduces the near-bottom flow and hence the bottom stress, that is, buoyancy shutdown in the bottom boundary layer. The model is not valid over the inner shelf. Assuming the same shelf parameters and forcing as before (except for the cross-shelf density gradient), the Chapman and Lentz (2005) model yields a reasonable cross-shelf density gradient and reproduces the observed $v^{\text {da }}$ (dash-dot line, Fig. 3). However, the steadystate density field in the model is vertically uniform, which is inconsistent with the observations, possibly because the model does not include the annual variation in surface heating or river discharges.

\section{c. Alongshelf transport}

A number of previous studies have made estimates of the alongshelf volume transport in the MAB (Beardsley et al. 1976; Ramp et al. 1988; Biscaye et al. 1994; Loder et al. 1998; Churchill and Berger 1998; Savidge and Bane 2001; Flagg and Dunn 2003). The observed relationship between $v^{\text {da }}$ and $h$ (Fig. 3) provides a potentially more robust volume transport estimate since the relationship is based on a larger number of currentmeter records. Volume transports are estimated as

$$
Q=-\int_{0}^{x^{\mathrm{sb}}} h v^{\mathrm{da}}(h) d x
$$

where $x^{\mathrm{sb}}$ is the offshore location of the shelfbreak and $v^{\mathrm{da}}=-1.8 \times 10^{-2}-7.0 \times 10^{-4} h$ from the linear regression analysis in section 5a (mks units). For a linear bottom slope, the volume transport is proportional to $h^{3}$, which means the transport estimate is sensitive to the choice of $x^{\mathrm{sb}}$. Volume transports were estimated by numerically integrating (18) for six cross-shelf transects of water depth $h(x)$ within the MAB (Table 2). Transports are similar to the previous estimates cited above. The transport estimates decrease from Cape Cod to North Carolina because of the corresponding reduction in cross-sectional area, since $v^{\text {da }}$ does not vary along isobaths. The alongshelf transport divergence is roughly constant and corresponds to a depth-averaged offshore flow of slightly less than $1 \mathrm{~cm} \mathrm{~s}^{-1}$ at the shelf break.

The transport estimates from (18) are not the entire shelf-water transport. The shelf-slope front separating the shelf water from the slope water is typically near the shelf break at the bottom but extends farther offshore 
TABLE 2. Alongshelf volume transport estimates at six crossshelf transects within the MAB. The position of the coastal end of each transect and the water depth at the shelf break are also listed.

\begin{tabular}{lcccc}
\hline \hline \multicolumn{1}{c}{ Transect } & $\begin{array}{c}\text { Lat } \\
\left({ }^{\circ} \mathrm{N}\right)\end{array}$ & $\begin{array}{c}\text { Lon } \\
\left({ }^{\circ} \mathrm{W}\right)\end{array}$ & $\begin{array}{c}\text { Shelfbreak } \\
\text { depth }(\mathrm{m})\end{array}$ & $\begin{array}{c}\text { Transport } \\
\left(10^{6} \mathrm{~m}^{3} \mathrm{~s}^{-1}\right)\end{array}$ \\
\hline Georges Bank & $41^{\circ} 16.8^{\prime}$ & $67^{\circ} 43.2^{\prime}$ & 95 & 0.44 \\
Cape Cod & $41^{\circ} 20.2^{\prime}$ & $70^{\circ} 33.4^{\prime}$ & 125 & 0.64 \\
Long Island & $40^{\circ} 45.0^{\prime}$ & $72^{\circ} 49.2^{\prime}$ & 90 & 0.41 \\
New Jersey & $39^{\circ} 27.7^{\prime}$ & $74^{\circ} 15.7^{\prime}$ & 85 & 0.27 \\
Maryland & $38^{\circ} 1.8^{\prime}$ & $75^{\circ} 13.2^{\prime}$ & 75 & 0.16 \\
North Carolina & $36^{\circ} 14.7^{\prime}$ & $75^{\circ} 42.5^{\prime}$ & 45 & 0.09
\end{tabular}

near the surface (Linder and Gawarkiewicz 1998). Since the transport estimates from (18) are for the area onshore of the shelf break (a particular isobath), they do not include the shelf-water transport offshore of the shelf break. Therefore the total shelf-water transport is almost certainly larger and may be conserved alongshelf if the shelf-water transport offshore of the shelf break increases from north to south.

\section{Summary}

Analysis of moored current observations from the Middle Atlantic Bight shelf reveal a consistent mean circulation pattern. Time series longer than 200 days were used in the analysis so that the standard error of the mean flow is $1 \mathrm{~cm} \mathrm{~s}^{-1}$ or less. A coordinate system is used with the alongshelf direction aligned with the mean depth-averaged flow, which tends to be roughly along-isobath.

The mean depth-averaged flow is equatorward, alongshelf, and increases linearly with increasing water depth from $3 \mathrm{~cm} \mathrm{~s}^{-1}$ at the $15-\mathrm{m}$ isobath to $10 \mathrm{~cm} \mathrm{~s}^{-1}$ at the 100-m isobath (Fig. 3). The mean alongshelf flow increases with height above the bottom (Fig. 4) with a maximum vertical shear of $2-4 \times 10^{-2} \mathrm{~s}^{-1}$ near the bottom decreasing to approximately zero more than 50 $\mathrm{m}$ above the bottom (Fig. 5).

The depth-averaged cross-shelf flow is zero by definition in the coordinate system used. The mean crossshelf circulation is weak, but exhibits a consistent crossshelf and vertical structure (Fig. 2). The near-surface flow is typically offshore but variable ranging from -2 to $4 \mathrm{~cm} \mathrm{~s}^{-1}$. The "interior" mean cross-shelf flow is onshore at about $1 \mathrm{~cm} \mathrm{~s}^{-1}$ and remarkably constant, both spatially and between different field programs (Fig. 7). The near-bottom mean flow increases with water depth from $-1 \mathrm{~cm} \mathrm{~s}^{-1}$ (onshore) near the coast to 4 $\mathrm{cm} \mathrm{s}^{-1}$ (offshore) over the slope (Fig. 8). The change in sign of the near-bottom cross-shelf flow occurs at about the 50-m isobath, consistent with Bumpus' results based on bottom drifter returns. The cross-shelf profiles have a two-layer structure over the inner shelf with offshore flow near the surface and onshore flow near the bottom and a three-layer structure over the mid- and outer shelf with offshore flow near the surface and bottom, and onshore flow in the interior (Fig. 6). Assuming no alongshelf variations in the circulation, the convergence of the interior onshore transport due to the decreasing water depth feeds the divergence of the offshore flow in the bottom boundary layer as shown schematically in Fig. 2. There is also upwelling over the inner shelf where the near-bottom onshore flow feeds the offshore transport in the surface boundary layer.

The observed circulation is consistent with a steady, two-dimensional dynamical model (developed in section 3) similar to a model proposed by Csanady (1976). The cross-shelf momentum balance is assumed to be geostrophic. The mean equatorward alongshelf flow is driven by a large-scale, alongshelf pressure gradient (or some other spatially uniform body force), a cross-shelf buoyancy forcing associated primarily with the crossshelf salinity gradient, and an alongshelf wind stress. Thus, in the depth-averaged alongshelf momentum balance, the alongshelf pressure gradient (or other body force) is balanced by the wind stress and bottom stress.

Estimates of the near-surface and near-bottom crossshelf transports are in rough agreement with Ekman transports associated with the wind stress and bottom stress, respectively (Fig. 9). Measurements of the mean alongshelf pressure gradient $P_{y}$ do not exist. However, independent estimates of $P_{y}$ based on the depthaveraged alongshelf momentum balance and assuming the interior onshore flow is geostrophic are significantly correlated, though the geostrophic estimates are about 1.6 times larger than the estimates from the depthaveraged momentum balance. Both estimates indicate that the mean alongshelf pressure gradient decreases to near zero in the region south of Chesapeake Bay. North of Chesapeake Bay, the mean alongshelf sea surface slope is estimated to be $3.7 \times 10^{-8}$ based on the depthaverage momentum balance. The associated alongshelf pressure gradient contribution to the depth-averaged alongshelf flow is about 8 times larger than the crossshelf buoyancy force contribution estimated from historical hydrographic data. The model reproduces the observed magnitude and linear increase with water depth in both the depth-averaged alongshelf flow over the mid- and outer shelf (Fig. 3) and in the nearbottom, cross-shelf flow, including the reversal to onshore flow shoreward of the 50-m isobath (Fig. 8). The increase in the near-bottom offshore flow is a result of the changing relative magnitudes of the geostrophic interior onshore flow and the offshore flow driven by the bottom stress. 
Acknowledgments. The author is grateful to various researchers (too numerous to list) that collected the historical data used here. The remarkably consistent picture of the mean circulation that emerged from this study is a testament to the care and effort that went into collecting these observations. Collection of the observations was funded by Department of Energy, Minerals Management Service, National Science Foundation, National Oceanic and Atmospheric Administration, and the Office of Naval Research. John Trowbridge graciously provided covariance estimates of bottom stress essential to this study. The author also appreciates comments and suggestions on an early draft of this manuscript by Bob Beardsley, Ken Brink, and Melanie Fewings. The author is especially grateful to Jamie Pringle for pointing out several typographical errors in an early version of the model description and for motivating a more complete and clearer derivation of the model. This research was funded by Ocean Sciences Division of the National Science Foundation under Grants OCE-820773, OCE-841292, and OCE-848961.

\section{APPENDIX A}

\section{Estimate of Depth-Averaged Alongshelf Velocity}

The alongshelf velocity is estimated here assuming the cross-shelf momentum balance includes the stress divergence term $\tau_{z}^{x}$,

$$
-\rho_{o} f v=-P_{x}+\tau_{z}^{x}
$$

rather than assuming a geostrophic balance as in section $3 \mathrm{c}$. The alongshelf flow is decomposed into a geostrophic component, $v^{g}=P_{x} / \rho_{o} f$, and Ekman velocities in the surface and bottom boundary layers,

$$
v^{s e}=-\frac{\tau^{s x}}{\rho_{o} f \delta^{s}} \quad \text { and } \quad v^{b e}=\frac{\tau^{b x}}{\rho_{o} f \delta^{b}} .
$$

The depth-averaged alongshelf velocity $v^{\text {da }}$ is

$$
\begin{aligned}
v^{\mathrm{da}} & =\frac{1}{h} \int_{-h}^{0} v^{g} d z+\frac{\delta^{s}}{h} v^{s e}+\frac{\delta^{b}}{h} v^{b e} \\
& =\frac{1}{h} \int_{-h}^{0} v^{g} d z-\frac{\tau^{s x}}{\rho_{o} f h}+\frac{\tau^{b x}}{\rho_{o} f h} .
\end{aligned}
$$

The geostrophic component is given by (10). However, the alongshelf velocity at the bottom $v^{\text {bot }}$ is

$$
v^{\text {bot }}=v^{b e}+v^{g b}
$$

where $v^{g b}$ is the geostrophic velocity at the bottom. Equating (11) and (A4), using (A2), and solving for $v^{g b}$ yields

$$
v^{g b}=\frac{\tau^{s y}}{r \rho_{o}}-\frac{g h \eta_{y}}{r}-\frac{1}{r} \int_{-h}^{0} B_{y} d z-\frac{\tau^{b x}}{\rho_{o} f \delta^{b}} .
$$

Substituting (10) and (A4) into (A3), assuming that $\tau^{b x}=\rho_{o} r u^{b}$ (appendix B), and getting $u^{b}$ from (8), the depth-averaged alongshelf velocity is

$$
\begin{aligned}
v^{\mathrm{da}}= & \frac{\tau^{s y}}{\rho_{o} r}\left[1+\gamma^{2}\left(1-\frac{\delta^{b}}{h}\right)\right]-\gamma \frac{\delta^{b}}{h} \frac{\tau^{s x}}{\rho_{o} r}-\frac{g h \eta_{y}}{r}\left[1+\gamma^{2}\left(1-\frac{\delta^{b}}{h}\right)^{2}\right] \\
& -\frac{1}{r}\left[\int_{-h}^{0} B_{y} d z+\gamma^{2}\left(1-\frac{\delta^{b}}{h}\right) \int_{-h+\delta^{b}}^{0} B_{y} d z\right]-\frac{1}{f h} \int_{-h}^{0} R_{x} d z
\end{aligned}
$$

where $\gamma=r / f \delta^{b}$. For the parameters used here $(r=$ $2.5 \times 10^{-4} \mathrm{~m} \mathrm{~s}^{-1}, f=0.9 \times 10^{-4} \mathrm{~s}^{-1}$, and $\left.\delta^{b}=15 \mathrm{~m}\right)$, $\gamma^{2} \approx 0.03$. Since the model is only valid for $\delta^{b} / h<1$, the terms containing $\gamma^{2}$ are small. The cross-shelf wind stress term is also small except over the inner shelf, since $\gamma \approx 0.18, \delta^{b} / h<1$, and $\tau^{s x}$ is comparable to $\tau^{s y}$ (see also Fewings et al. 2008). Neglecting the terms involving $\gamma^{2}$ and the cross-shelf wind stress term, (A6) reduces to (12).

\section{APPENDIX B}

\section{Bottom Stress Estimation}

To estimate bottom stress at each of the MAB sites, a quadratic drag coefficient $C_{D}$ as a function of height above the bottom $z^{\prime}$ was determined using near-bottom covariance stress estimates from the southern flank of Georges Bank [J. Trowbridge 2006, personal communication; see also Werner et al. (2003) for details of the measurements]. The basic approach for making the covariance stress estimates, including removal of wave biases, is outlined in Shaw et al. (2001) and Trowbridge (1998). The drag coefficient was estimated as the slope of a linear regression of the form

$$
\left|\overline{u^{\prime} w^{\prime}}\right|=C_{D}\left(z^{\prime}\right)\left|\mathbf{u}\left(z^{\prime}\right)\right|^{2}+b
$$

where $\left|\overline{u^{\prime} w^{\prime}}\right|$ is the magnitude of the covariance stress estimate and $b$ is an intercept. Comparison with $C_{D}$ 


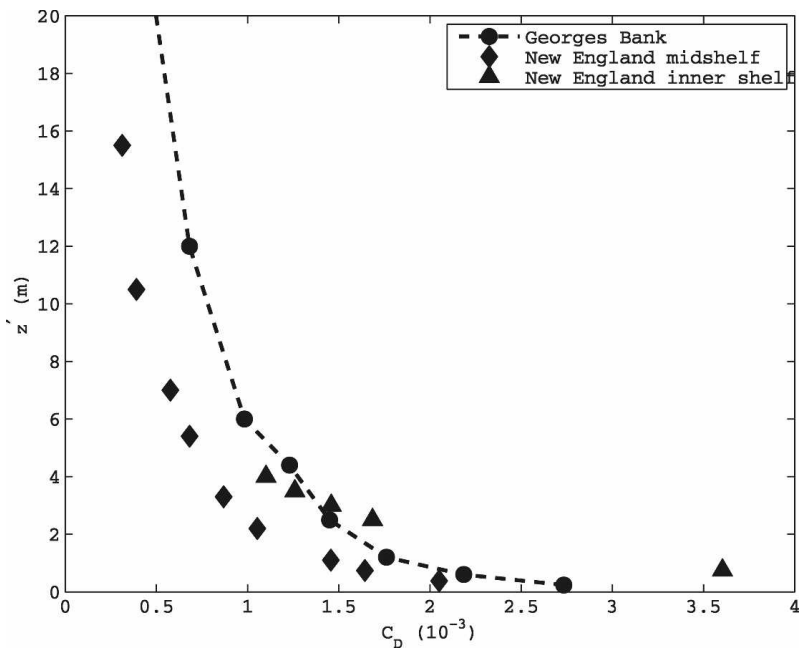

FIG. B1. Near-bottom profiles of the drag coefficient $C_{d}$ estimated from covariance estimates of near-bottom stress from three sites: Georges Bank, New England midshelf, and New England inner shelf.

estimates from a midshelf (Shaw et al. 2001) and an inner-shelf site (J. Trowbridge 2006, personal communication), both south of Cape Cod, Massachusetts, indicate about a factor-of- 2 variation in the near-bottom $C_{D}$ profiles from the three sites (Fig. B1). The New England midshelf site was located in a region of silt (called the "mud patch"), and $C_{D}$ is relatively small because of near-bottom stratification by suspended sediment (J. Trowbridge 2006, personal communication).

Time series of bottom stress $\boldsymbol{\tau}^{b}$ were estimated for each of the 29 sites where hourly time series were available. The drag coefficient $C_{D}$ was estimated by interpolating the Georges Bank $C_{D}$ profile to the height of the current meter nearest the bottom and then bottom stress was estimated using a quadratic drag law $\tau^{b}=$ $C_{D} \mathbf{u}^{b}\left|\mathbf{u}^{b}\right|$, where $\mathbf{u}^{b}$ is the unfiltered hourly near-bottom current vector.

Comparison of the mean bottom stresses $\tau^{b}$ to the mean near-bottom velocities $\mathbf{u}^{b}$ indicates that a linear drag law of the form

$$
\tau^{b}=\rho_{o} r \mathbf{u}^{b}
$$

provides an accurate estimate of the mean bottom stress (Fig. B2). The correlation is 0.90 for the crossshelf component and 0.84 for the alongshelf component, both significant at the $95 \%$ confidence level. The estimated linear drag coefficient is $r=2.5 \times 10^{-4} \mathrm{~m} \mathrm{~s}^{-1}$ for both components, with $95 \%$ confidence intervals of $\pm 0.5 \times 10^{-4} \mathrm{~m} \mathrm{~s}^{-1}$ for the cross-shelf component and $\pm 0.6 \times 10^{-4} \mathrm{~m} \mathrm{~s}^{-1}$ for the alongshelf component.

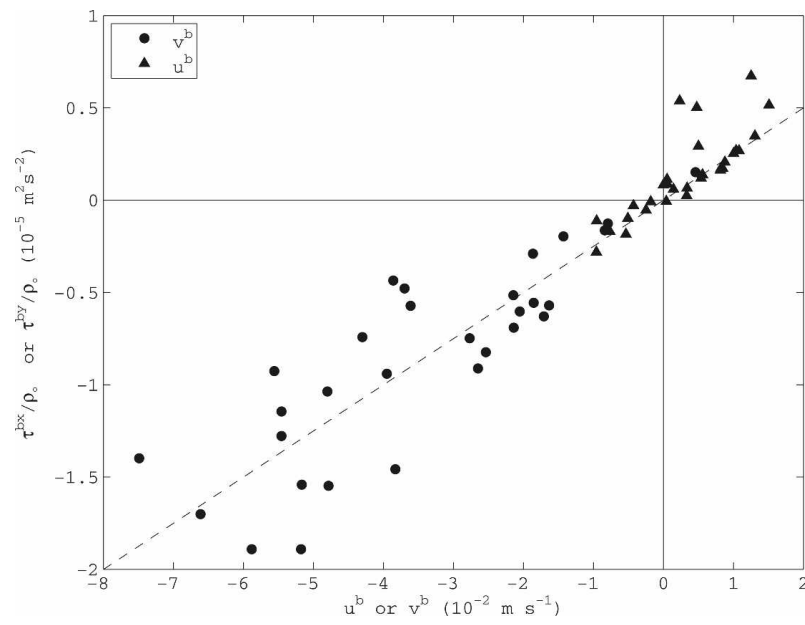

FIG. B2. Comparison of mean bottom stress with linear drag law using mean near-bottom velocity for all the mooring sites. The correlations are 0.90 and 0.84 for cross-shelf and alongshelf components, respectively. The best-fit linear drag coefficient for both components is $r=2.5 \times 10^{-4} \mathrm{~m} \mathrm{~s}^{-1}$.

\section{REFERENCES}

Aikman, F., III, H. W. Ou, and R. W. Houghton, 1988: Current variability across the New England continental shelf-break and slope. Cont. Shelf Res., 8, 625-651.

Austin, T. C., and Coauthors, 2002: A network-based telemetry architecture developed for the Martha's Vineyard Coastal Observatory. IEEE J. Oceanic Eng., 27, 228-234.

Beardsley, R. C., 1987: A comparison of the vector-averaging current meter and new Edgerton, Germeshausen, and Grier, Inc., vector-measuring current meter on a surface mooring in CODE 1. J. Geophys. Res., 92, 1845-1860.

— Mid-Atlantic Bight. J. Phys. Oceanogr., 9, 612-619.

— shelf circulation in the Middle Atlantic Bight. Evolution of Physical Oceanography: Scientific Surveys in Honor of Henry Stommel, B. A. Warren and C. Wunsch, Eds., MIT Press, 198-233.

, and D. V. Hansen, 1976: Physical oceanography of the Middle Atlantic Bight. Middle Atlantic Continental Shelf and the New York Bight, M. G. Gross, Ed., American Society of Limnology and Oceanography, 20-34.

,-- L. Huff, J. McCullough, and J. Scott, 1981: CMICE: A near-surface current meter intercomparison experiment. Deep-Sea Res., 28, 1577-1603.

—, D. C. Chapman, K. H. Brink, S. R. Ramp, and R. Schlitz, 1985: The Nantucket Shoals Flux Experiment (NSFE79). Part I: A basic description of the current and temperature variability. J. Phys. Oceanogr., 15, 713-748.

Berger, T. J., W. C. Boicourt, J. H. Churchill, P. Hamilton, R. J. Wayland, and D. R. Watts, 1994: A physical oceanographic field program offshore of North Carolina. Tech. Rep. MMS 94, Science Applications International Corporation, 463 pp.

Bigelow, H. B., 1915: Exploration of the coast water between Nova Scotia and Chesapeake Bay, July and August, 1913, by the U.S. Fisheries Schooner Grampus. Bull. Museum Comp. Zool., 59, 152-359. 
_ 1933: Studies of the waters on the continental shelf, Cape Cod to Chesapeake Bay, I, The cycle of temperature. Pap. Phys. Oceanogr. Meteor., 2, 1-135.

- and M. Sears, 1935: Studies of the waters on the continental shelf, Cape Cod to Chesapeake Bay, II, Salinity. Pap. Phys. Oceanogr. Meteor., 4, 1-94.

Biscaye, P. E., C. N. Flagg, and P. G. Falkowski, 1994: The Shelf Edge Exchange Processes experiment. SEEP-II: An introduction to hypotheses, results and conclusions. Deep-Sea Res., 41, 231-252.

Brink, K. H., R. Limeburner, and R. C. Beardsley, 2003: Properties of flow and pressure over Georges Bank as observed with near-surface drifters. J. Geophys. Res., 108, 8001, doi:10.1029/ 2001JC001019.

Brown, W. S., N. R. Pettigrew, and J. D. Irish, 1985: The Nantucket Shoals Flux Experiment (NSFE79). Part II: The structure and variability of across-shelf pressure gradients. J. Phys. Oceanogr., 15, 749-771.

Bumpus, D. F., 1965: Residual drift along the bottom on the continental shelf in the Middle Atlantic Bight area. Limnol. Oceanogr., 10, R50-R53.

_ 1973: A description of the circulation on the continental shelf of the east coast of the United States. Prog. Oceanogr., 6, 111-157.

Bush, K., and S. L. Kupferman, 1980: Wind stress direction and the alongshore pressure gradient in the Middle Atlantic Bight. J. Phys. Oceanogr., 10, 469-471.

Butman, B., 1987: Processes causing surficial sediment movement. Georges Bank, R. H. Backus, Ed., MIT Press, 147-162.

— J. W. Loder, and R. C. Beardsley, 1987: The seasonal mean circulation: Observation and theory. Georges Bank, R. H. Backus, Ed., MIT Press, 125-138.

Chapman, D. C., and R. C. Beardsley, 1989: On the origin of shelf water in the Middle Atlantic Bight. J. Phys. Oceanogr., 19, 384-391.

— , and S. J. Lentz, 2005: Acceleration of a stratified current over a sloping bottom, driven by an alongshelf pressure gradient. J. Phys. Oceanogr., 35, 1305-1317.

_ J. A. Barth, and R. C. Beardsley, 1986: On the continuity of mean flow between the Scotian shelf and the Middle Atlantic Bight. J. Phys. Oceanogr., 16, 758-772.

Churchill, J. H., and T. J. Berger, 1998: Transport of Middle Atlantic Bight shelf water to the Gulf Stream near Cape Hatteras. J. Geophys. Res., 103, 30 605-30 621.

Codiga, D. L., 2005: Interplay of wind forcing and buoyant discharge off Montauk Point: Seasonal changes to velocity structure and a coastal front. J. Phys. Oceanogr., 35, 1068-1085.

Csanady, G. T., 1976: Mean circulation in shallow seas. J. Geophys. Res., 81, 5389-5399.

_ 1978: The arrested topographic wave. J. Phys. Oceanogr., 8, 47-62.

_ J. H. Churchill, and B. Butman, 1988: Near-bottom currents over the continental slope in the Mid-Atlantic Bight. Cont. Shelf Res., 8, 653-671.

Dever, E. P., 1997: Wind-forced cross-shelf circulation on the northern California shelf. J. Phys. Oceanogr., 27, 1566-1580.

Fewings, M., S. J. Lentz, and J. Fredericks, 2008: Observations of cross-shore flow driven by cross-shore winds over the inner continental shelf. J. Phys. Oceanogr., in press.

Flagg, C. N., and M. Dunn, 2003: Characterization of the mean and seasonal flow regime on Georges Bank from shipboard acoustic Doppler current profiler data. J. Geophys. Res., 108, 8002, doi:10.1029/2001JC001257.
,-- , D.-P. Wang, H. T. Rossby, and R. L. Benway, 2006: A study of the currents of the outer shelf and upper slope from a decade of shipboard ADCP observations in the Middle Atlantic Bight. J. Geophys. Res., 111, C06003, doi:10.1029/ $2005 J C 003116$.

Ford, W. L., J. R. Longard, and R. E. Banks, 1952: On the nature, occurrence and origin of cold low salinity water along the edge of the Gulf Stream. J. Mar. Res., 11, 281-293.

Fratantoni, P. S., and R. S. Pickart, 2003: Variability of the shelfbreak jet in the Middle Atlantic Bight: Internally or externally forced? J. Geophys. Res., 108, 3166, doi:10.1029/ 2002JC001326.

$\longrightarrow$, and - 2007: The western North Atlantic shelfbreak current system in summer. J. Phys. Oceanogr., 37, 2509-2533.

Garvine, R. W., 1991: Subtidal frequency estuary-shelf interaction: Observations near Delaware Bay. J. Geophys. Res., 96, 7049-7064

, 2004: The vertical structure and subtidal dynamics of the inner shelf off New Jersey. J. Mar. Res., 62, 337-371.

Gawarkiewicz, G., and C. A. Linder, 2006: Lagrangian flow patterns north of Cape Hatteras using near-surface drifters. Prog. Oceanogr., 70, 181-195.

Haidvogel, D. B., and K. H. Brink, 1986: Mean currents driven by topographic drag over the continental shelf and slope. $J$. Phys. Oceanogr., 16, 2159-2171.

Harris, C. K., B. Butman, and P. Traykovski, 2003: Winter-time circulation and sediment transport in the Hudson Shelf Valley. Cont. Shelf Res., 23, 801-820.

Holloway, G., 1992: Representing topographic stress for large scale ocean models. J. Phys. Oceanogr., 22, 1033-1046.

Irish, J. D., S. M. Kerry, P. D. Fucile, R. C. Beardsley, J. Lord, and K. H. Brink, 2005: U.S. GLOBEC Georges Bank Long-Term Moored Program: Part 1-Mooring configuration. Tech. Rep. 2005-11, Woods Hole Oceanographic Institution, Woods Hole, MA, 24 pp.

Iselin, C. O., 1939: Some physical factors which may influence the productivity of New England's coastal waters. J. Mar. Res., 2, 74-85.

Khatiwala, S. P., R. G. Fairbanks, and R. W. Houghton, 1999: Freshwater sources to the coastal ocean off northeastern North America: Evidence from $\mathrm{H}_{2}^{18} \mathrm{O} / \mathrm{H}_{2}^{16} \mathrm{O}$. J. Geophys. Res., 104, 18 241-18 255.

Large, W. G., and S. Pond, 1981: Open ocean momentum flux measurements in moderate to strong winds. J. Phys. Oceanogr., 11, 324-336.

Lentz, S. J., 2008: Seasonal variations in the circulation of the Middle Atlantic Bight continental shelf. J. Phys. Oceanogr., in press.

$\longrightarrow$, R. T. Guza, S. Elgar, F. Feddersen, and T. H. C. Herbers, 1999: Momentum balances on the North Carolina inner shelf. J. Geophys. Res., 104, 18 205-18 226.

_ K. Shearman, S. Anderson, A. Plueddemann, and J. Edson, 2003: Evolution of stratification over the New England shelf during the Coastal Mixing and Optics study, August 1996June 1997. J. Geophys. Res., 108, 3008, doi:10.1029/ 2001JC001121.

- M. Fewings, P. Howd, J. Fredericks, and K. Hathaway, 2008: Observations and a model of undertow over the inner continental shelf. J. Phys. Oceanogr., in press.

Linder, C. A., and G. Gawarkiewicz, 1998: A climatology of the shelfbreak front in the Middle Atlantic Bight. J. Geophys. Res., 103, 18 405-18 423.

Loder, J. W., B. Petrie, and G. Gawarkiewicz, 1998: The coastal 
ocean off northeastern North America: A large-scale view. The Sea, A. R. Robinson and K. H. Brink, Eds., The Global Coastal Ocean: Regional Studies and Syntheses, Vol. 11, John Wiley and Sons, 105-133.

Lozier, M. S., and G. Gawarkiewicz, 2001: Cross-frontal exchange in the Middle Atlantic Bight as evidenced by surface drifters. J. Phys. Oceanogr., 31, 2498-2510.

Manning, J. P., L. Y. Oey, D. Packer, J. Vitaliano, T. W. Finneran, K. W. You, and S. Fromm, 1994: Observations of bottom currents and estimates of resuspended sediment transport at the New York Bight 12-mile dumpsite. J. Geophys. Res., 99, 10 221-10 239.

Mayer, D. A., 1982: The structure of circulation: MESA physical oceanographic studies in New York Bight, 2. J. Geophys. Res., 87, 9579-9588.

- D. V. Hansen, and D. A. Ortman, 1979: Long-term current and temperature observation on the Middle Atlantic shelf. $J$. Geophys. Res., 84, 1776-1792.

Merryfield, W. J., P. F. Cummins, and G. Holloway, 2001: Equilibrium statistical mechanics of barotropic flow over finite topography. J. Phys. Oceanogr., 31, 1880-1890.

Munchow, A., and R. W. Garvine, 1993: Dynamical properties of a buoyancy-driven coastal current. J. Geophys. Res., 98, $20063-20078$

—, and R. J. Chant, 2000: Kinematics of inner shelf motions during the summer stratified seasons off New Jersey. J. Phys. Oceanogr., 30, 247-268.

Nelsen, T. A., P. E. Gadd, and T. L. Clarke, 1978: Wind-induced current flow in the upper Hudson Shelf Valley. J. Geophys. Res., 83, 6073-6081.

Pape, E. H., and R. W. Garvine, 1982: The subtidal circulation in Delaware Bay and adjacent shelf waters. J. Geophys. Res., 87, 7955-7970.

Pietrafesa, L. J., C. N. Flagg, L. Xie, G. L. Weatherly, and J. M. Morrison, 2002: The winter/spring 1996 OMP current, meteorological, sea state and coastal sea level fields. Deep-Sea Res., 49, 4331-4354.

Ramp, S. R., W. S. Brown, and R. C. Beardsley, 1988: The Nantucket Shoals Flux Experiment. 3. The alongshelf transport of volume, heat, salt, and nitrogen. J. Geophys. Res., 93, 14 03914054 .

Rennie, S., J. L. Largier, and S. J. Lentz, 1999: Observations of low-salinity coastal current pulses downstream of Chesapeake Bay. J. Geophys. Res., 104, 18 227-18 240.

Samelson, R. M., and J. S. Allen, 1987: Quasi-geostrophic topographically generated mean flow over the continental margin. J. Phys. Oceanogr., 17, 2043-2064.

Saunders, P. M., 1977: Wind stress on the ocean over the eastern continental shelf of North America. J. Phys. Oceanogr., 7, $555-566$.

Savidge, D. K., and J. M. Bane Jr., 2001: Wind and Gulf Stream influences on along-shelf transport and off-shelf export at Cape Hatteras, North Carolina. J. Geophys. Res., 106, $11505-11527$.

Schofield, O., T. Bergman, P. Bissett, J. F. Grassle, J. Kohut, M. Moline, and S. M. Glenn, 2002: The Long-Term Ecosystem Observatory: An integrated coastal observatory. IEEE J. Oceanic Eng., 27, 146-154.

Scott, J. T., and G. T. Csanady, 1976: Nearshore currents off Long Island. J. Geophys. Res., 81, 5401-5409.

Shaw, P.-T., L. J. Pietrafesa, C. N. Flagg, R. W. Houghton, and K.-H. Su, 1994: Low-frequency oscillations on the outer shelf in the southern Mid-Atlantic Bight. Deep-Sea Res., 41, 253 272.

- J. H. Trowbridge, and A. J. Williams III, 2001: Budgets of turbulent kinetic energy and scalar variance in the continental shelf bottom boundary layer. J. Geophys. Res., 106, 95519564.

Shearman, R. K., and S. J. Lentz, 2003: Dynamics of mean and subtidal flow on the New England shelf. J. Geophys. Res., 108, 3281, doi:10.1029/2002JC001, 417.

Smith, P. C., 1983: The mean and seasonal circulation off southwest Nova Scotia. J. Phys. Oceanogr., 13, 1034-1054.

Stommel, H., and A. Leetmaa, 1972: Circulation on the continental shelf. Proc. Natl. Acad. Sci. USA, 69, 3380-3384.

Sturges, W., 1977: Comment on "Nearshore currents off Long Island" by J. T. Scott and G. T. Csanady. J. Geophys. Res., 82, 1451-1452.

Sverdrup, H. U., M. W. Johnson, and R. H. Fleming, 1942: The Oceans: Their Physics, Chemistry, and General Biology. Prentice-Hall, $1087 \mathrm{pp}$.

Trowbridge, J. H., 1998: On a technique for measurement of turbulent shear stress in the presence of surface waves. J. Atmos. Oceanic Technol., 15, 290-298.

_ , and S. J. Lentz, 1991: Asymmetric behavior of an oceanic boundary layer above a sloping bottom. J. Phys. Oceanogr., 21, 1171-1185.

Ullman, D. S., and D. L. Codiga, 2004: Seasonal variation of a coastal jet in the Long Island Sound outflow region based on HF radar and Doppler current observations. J. Geophys. Res., 109, C07S06, doi:10.1029/2002JC001660.

Walsh, J., G. Csanady, D. Spencer, and P. Biscaye, 1988: The 1983-1984 Shelf Edge Exchange Processes (SEEP)-I Experiment: Hypothesis and highlights. Cont. Shelf Res., 8, 435456.

Wang, D.-P., 1982: Effects of continental slope on the mean shelf circulation. J. Phys. Oceanogr., 12, 1524-1526.

Werner, S. R., R. C. Beardsley, S. J. Lentz, D. L. Herbert, and N. S. Oakey, 2003: Observations and modeling of the tidal bottom boundary layer on the southern flank of Georges Bank. J. Geophys. Res., 108, 8005, doi:10.1029/2001JC001271. 